\title{
PEPPERDINE
}

UNIVERSITY

Pepperdine Law Review

Volume 36 | Issue 4

Article 4

$5-15-2009$

\section{"Mortal [K]ombat in cleats": An Examination of the Effectiveness of the National Football League's Disability Plan and Its Impact on Retired Players}

Brett Edwin LoVellette

Follow this and additional works at: https://digitalcommons.pepperdine.edu/plr

Part of the Disability Law Commons, and the Entertainment, Arts, and Sports Law Commons

\section{Recommended Citation}

Brett Edwin LoVellette "Mortal [K]ombat in cleats": An Examination of the Effectiveness of the National Football League's Disability Plan and Its Impact on Retired Players, 36 Pepp. L. Rev. Iss. 4 (2009) Available at: https://digitalcommons.pepperdine.edu/plr/vol36/iss4/4

This Comment is brought to you for free and open access by the Caruso School of Law at Pepperdine Digital Commons. It has been accepted for inclusion in Pepperdine Law Review by an authorized editor of Pepperdine Digital Commons. For more information, please contact bailey.berry@pepperdine.edu. 


\section{"Mortal $[K]$ ombat in cleats": An Examination of the Effectiveness of the National Football League's Disability Plan and Its Impact on Retired Players}

I. INTRODUCTION

II. THE BIRTH OF THE NFLPA AND THE EVOLUTION OF NFL DISABILITY BENEFITS

III. STRUCTURE OF THE PLAN UNDER ERISA

IV. FILING A DISABILITY CLAIM

A. The Process Itself

B. Discretion Given to the Retirement Board

C. Federal Court Appeal

V. APPEALING A DECISION OF THE RETIREMENT BOARD DENYING BENEFITS IN FEDERAL COURT: A DAUNTING TASK

A. The Tragic Life and Times of Mike Webster

B. Court Cases Affirming the Retirement Board's Decision

VI. PERCEIVED PROBLEMS WITH THE CURRENT PLAN
A. The Widespread Use of Astroturf
B. The Phantom Concussion Epidemic
C. Slow Administration of Claims
D. Is the Plan Really All That Bad?

VII. SUGGESTIONS FOR IMPROVING THE PLAN

A. Employ Better Phraseology

1. Paul Solotaroff, Casualties of the NFL, MEN'S JouRNAL, Aug. 2007, available at http://web.archive.org/web/20071124071 842/http:/www.mensjournal.com/feature/M162/M162_Cas ualtiesoftheNFL.html ("Post-mortem exams of Andre Waters (suicide at 44), Terry Long (suicide at 45), Justin Strzelcyzk (car crash at 36), Mike Webster (heart attack at 50)-showed staggering brain damage in men so young and affirmed that football is no longer a contact sport but real-life Mortal $[K]$ ombat in cleats."). Mortal Kombat is a virtual reality video game starring "seven fictional characters, each of which has a unique fighting style, including method of killing opponents, or 'finishing move.' The characters advance through the various levels of the game by using increasing levels of violence ...." Wilson v. Midway Games, Inc., 198 F. Supp. 2d 167, 170 (D. Conn. 2002). 


\author{
B. Eliminate or Extend Timing Deadlines on Retroactive \\ Disability Claims \\ C. Give Former Players Representation on the Retirement \\ Board and Increased Access to Plan Information \\ D. Select NFLPA Leaders That Will Effectively Represent All \\ Players in Collective Bargaining \\ VIII. CONCLUSION
}

Since his injury on the gridiron, [the retired football player] has met his most implacable foe on the field of intractability against a home team, the National Football League's retirement plan. Each time he nears the goal line and is about to obtain the disability benefits which the plan promises to injured players, the yard markers are changed and the clock is stopped. ${ }^{2}$

\title{
I. INTRODUCTION
}

"There's a reason that numerous NFL players throw up before every game, and it's not because they're nervous about missing an assignment on national television. It's because they're about to engage in the closest thing to hand-to-hand combat that most non-soldiers will ever experience." former National Football League (NFL) ${ }^{4}$ quarterback Phil Simms once

2. Armstrong v. Bert Bell NFL Player Ret. Plan, 646 F. Supp. 1094, 1095 (D. Colo. 1986).

3. Michael Silver, Harsh Reality of Brutal Sport, YaHOO! SPORTS, Nov. 27, 2007, http://sports.yahoo.com/nfl/news?slug=ms-violentnature1 12707\&prov=yhoo\&type=lgns.

4. The sport of football traces its humble beginnings to November 6,1869 , when Rutgers and Princeton played the first college football game ever, using modified London Football Association rules. NFL.com, NFL History by Decade 1869-1910, http://www.nfl.com/history/chronology/18691910 (last visited Mar. 25, 2009). In 1902, "[b]aseball's Philadelphia Athletics . . . and the Philadelphia Phillies formed professional football teams, joining the Pittsburgh Stars in the first attempt at a pro football league, named the National Football League." Id. On January 15, 1967, the Green Bay Packers defeated the Kansas City Chiefs 35-10 at the Memorial Coliseum in Los Angeles, California, in what was dubbed the "First World Championship Game," or "Super Bowl I." NFL.com, NFL History: First World Championship Game AFL vs. NFL, http://www.nfl.com/super bowl/history/recap/sbi (last visited Mar. 25, 2009). The winning players received a purse of $\$ 15,000$ each. Id. In 1972, the CBS television broadcast of Super Bowl VI was "viewed in an estimated 27,450,000 homes, the top-rated one-day telecast ever." NFL.com, NFL History by Decade 19711980, http://www.nfl.com/history/chronology/1971-1980 (last visited Mar. 25, 2009). By 1983, the NFL was composed of sixteen teams. NFL.com, NFL History by Decade 1981-1990, http://www.nfl.com/history/chronology/1981-1990 (last visited Mar. 25, 2009). Today, the NFL is composed of thirty-two teams and is divided into two conferences, the AFC and the NFC, which are each subdivided into four four-team divisions. NFL.com, Teams, http://www.nfl.com/teams (last visited Mar. 25, 2009). The tremendous growth of the NFL and its popularity in the United States is difficult to dispute. Attendance for all 2005 football games was $21,792,096$, which translates to the NFL setting "an all-time paid attendance record . . . for the fourth consecutive season." NFL.com, NFL History by Decade 2001-, http://www.nfl.com/history/ chronology/2001- (last visited Mar. 25, 
2009). Moreover, the Pittsburgh Steelers 2006 victory over the Seattle Seahawks in Super Bowl XL was viewed by a staggering 141.1 million television viewers, "making it the second-most watched program in U.S. television history." Id. No wonder the league "generated upwards of $\$ 6$ billion in revenue during the 2006 fiscal year." Michael McCann, No Easy Answers: NFL Retirement System Not as Bad, or Good, as Argued, SPORTS ILlUSTRATED, Sept. 18, 2007, available at $\mathrm{http} / /$ vault.sportsillustrated.cnn.com/vault/article/web/COM1063285/index.htm (emphasis added). In this comment, the NFL is also referred to as "the league."

5. Phil Simms with Vic Carucci, Sunday Morning Quarterback: GoING DeEP ON THE Strategies, MYTHS, AND MAYHEM OF FoOTBALl 156 (2004). Simms goes on to observe that "[t]he defender hits you and he's so proud that he has really laid it on you-that he has crushed you. $\mathrm{He}$ is the biggest, baddest man in the world." Id. at 159. Hall of Fame football player Sam Huff echoed such sentiments when describing the purpose of the game: "We try to hurt everybody. We hit each other as hard as we can. This is a man's game." RICHARD WHITTINGHAM, SUNDAY'S HEROES: NFL LEGENDS TALK ABOUT THE TimES OF THEIR LIVES 88 (2003). Another former NFL player, Rosie Grier, recalls a 1965 game where he hit Gale Sayers "so hard near the line of scrimmage $I$ thought my shoulder must have busted him in two." Id. at 44 (emphasis added). Furthermore, Lawrence Taylor, in reflecting upon his NFL career, notes one instance where he was "just killing [his opponent], just hitting him with one hand and driving his ass back into the quarterback. It was one of [Taylor's] finest hours as a defensive player . ..." BOB MCCULLOUGH, My Greatest Day In Football: The Legends of Football Recount Their Greatest MOMENTS 244 (2001). In other words, as former Los Angeles Rams player Les Richter once stated, "[i]f you don't like to knock somebody down, you have no business in this game." WHITTINGHAM, supra, at 112.

6. Two separate accounts of the 1938 NFL title game make this point abundantly clear. The game, in which the New York Giants defeated the Green Bay Packers 23-17, was "so exciting [and] .. . filled with mayhem" that International News Service reporter, Arthur "Bugs" Baer, reported the following:

It was a game of vibrating behemoths against fermenting Goliaths. Every man on the field was six feet tall, three feet wide and a yard thick. There was every kind of official on the turf except the one they needed most. And that was a knockdown timer. When the two lines rushed at each other it was like a freight train kissing the depot. You could hear the crash from the rockbound shores of Maine to far prettier places. The score, 2317 , sounds like the little-potato-hard-to-peel had met the lumberyard skull busters who decided to mash them instead. It was a backwoods vendetta in the high rent district. With the winners getting about $\$ 135$ extra per man, it was this extra bit of muscular bribery that made the lads go to town like a wolf in famine. The boys were as earnest as a sneak thief in a lock and key store. And as tough as veal breaded in marble dust. They went at each other like dogs meeting in a sausage machine. And mixed like the stuff they put in a Martini. It was a throwback to the apes. Twenty-two muggs got an assist on the play and the apes got credit for the putout .... It was mostly a barroom fight outdoors. Close to 50,000 innocent bystanders looked upon the resumption of gang warfare in America. It was terrific.

WhITTINGHAM, supra note 5, at 109, 111. Not to be outdone, the New York Times published the following account of the same rugged championship football game:

What a frenzied battle this was! The tackling was fierce and the blocking positively vicious. In the last drive every scrimmage pile-up saw a Packer tackler stretched on the ground ... . As for the Giants, they really were hammered to a fare-thee-well. Johnny Dell Isola was taken to St. Elizabeth's hospital with a spinal concussion that just missed 
characteristic certainly defines the modern game. ${ }^{7}$ Consequently, a football career in the NFL is frequently short-lived and the risk of injury is high. ${ }^{8}$ On average, an NFL career "lasts only three and a half seasons, usually occurring between ages 21 to $25 . "$ In fact, the average life expectancy for

being a fractured vertebra. Ward Cuff suffered a possible fracture of the sternum. Mel Hein, kicked in the cheekbone at the end of the second quarter, suffered a concussion of the brain that left him temporarily bereft of his memory. He came in to the final quarter and finished the game. Leland Shaffer sustained a badly sprained ankle. The play for the full sixty vibrant minutes was absolutely ferocious. No such blocking and tackling by two football teams ever had been seen at the Polo Grounds. Tempers were so frayed and tattered that stray punches were tossed around all afternoon. This was the gridiron sport at its primitive best.

Id. at 19.

7. Former Detroit Lions running back Barry Sanders recounts his first NFL game in a recent book:

In that first game it seemed like bodies were whizzing by me like bullets and colliding

like cymbals. No one in their right mind would throw themselves off a roof over and over and over again, and yet that's what we did to our bodies once a week, nine months a year, until we left the game or the game left us.

Barry Sanders with Mark E. MCCORMICK, Barry SANDERS: Now You SEe Him . . . : His STORY IN HIS OWN WORDS 50 (2003); see also Sweeney v. Bert Bell NFL Player Ret. Plan, 961 F. Supp. 1381, 1385 (S.D. Cal. 1997) ("Playing professional NFL football is a stressful, violent, painful, and injury-riddled occupation that places extreme pressure on players to win."); Hackbart v. Cincinnati Bengals, Inc., 601 F.2d 516, 518 (10th Cir. 1979) ("[P]rofessional football is a species of warfare ...."). Former NFL running back Marshall Faulk puts it this way: "Football is violent. If you've got a problem with the guy in front of you, you hit him hard and try to knock his block off." Silver, supra note 3. Similarly, Phil Simms remarks, "When you stop playing, you're changing from-for lack of a better term-a violent life to a normal life." SIMMS, supra note 5, at 163. Kyle Turley, currently employed as an offensive lineman by the Kansas City Chiefs, quickly admits that "[e]very day, for $2 \frac{1}{2}$ hours of practice, it's violence .... You're hitting the same guy in practice, and if he goes harder than you think he should, the competition rises, and you just want to kill each other. Then, on game day, it escalates-you're going to war." Silver, supra note 3. Turley, who stands six-foot-five and tips the scales at 300 pounds, "once was forced to attend anger management classes by the NFL after a celebrated helmet-extraction on national television." Id. Interestingly, Turley even goes so far as to note that the thrill he gets from "impos[ing his] will" on the football field tempts him to act violently off the field: "You're in the arena, and you're bigger than life .... Do I want to (expletive) someone up in the real world? All the time. You're in the grocery store line and the person in front of you is taking forever ... and you want to drill somebody." Id.

8. During his tenure with the Green Bay Packers, former NFL great Reggie White offered the following memorable explanation for the high rate of injury in his profession:

The thing a defensive lineman has to watch, more than anything else, is the back of his

legs. With every snap, you've got 300,600 , maybe even 900 pounds of raw beef aiming to land on you. Could come from your blind side. Could come from a cut block from the side, or a chop block from the rear. Could just happen when you get "caught in the wash" beneath a tangled pile of bodies, pads, and helmets. Any play can be a careerbuster. Guys who survive long-term in the trenches have to have an ability to detect danger and adjust instantly.

REGGIE WHITE WITH JIM DENNEY, IN THE TRENCHES 81 (1996).

9. McCann, supra note 4. There are "some exceptional players who have long careers that extend 10 or twelve seasons and beyond, [but] most players only stay active for about three seasons." NFL Players Association, NFL Hopefuls FAQs, http://www.nflplayers.com/user/template. aspx? fmid=181 \&lmid=349 (last visited Mar. 25, 2009). 
NFL players is fifty-five years, and only fifty-two for linemen. ${ }^{10}$ Given the resulting transitory nature of an NFL career ${ }^{11}$ and the high likelihood of serious injury, ${ }^{12}$ the need for a pension plan to "promote lifetime financial security for employees" becomes apparent. ${ }^{13}$

The NFL Players Association (NFLPA) is the union for professional football players, and it strives to zealously pursue the interests of its players. ${ }^{14}$ One such interest is the implementation of a disability benefits plan conducive to the various needs of former players. ${ }^{15}$ For better or for worse, under the current plan ${ }^{16}$ and pursuant to federal law ${ }^{17}$ a six-person Retirement Board ${ }^{18}$ composed of representatives from both the NFL and the NFLPA $^{19}$ has nearly unbounded power and discretion to decide the fate of a former player's application for disability benefits. ${ }^{20}$

The physical and mental effects that years of playing in the NFL have had on numerous former professional football players came into vivid clarity when "[t]he treatment of retired NFL players took center stage in

10. Oversight of the NFL's Ret. System: Hearing Before the S. Comm. on Commerce, Sci. \& Transp., 110th Cong. (2007) [hereinafter Oversight Hearing] (statement of Brent Boyd, former NFL Player), available at http://commerce.senate.gov/public/index.cfm?FuseAction=Hearings.Hearing\& Hearing_ID=453a85ee-b12c-41cf-ae6c-f3235655bc75 (follow link to Mr. Brent Boyd).

11. See supra note 9 and accompanying text (average NFL career lasts three and a half seasons).

12. See supra notes 1-10 and accompanying text (discussing the high levels of violence and injuries in the NFL).

13. Michael McCann, a law professor at Mississippi College School of Law, comments on such a need:

[C]onsider why NFL players have a retirement system, which effectively includes a pension plan and a disability plan. Like any pension plan, the NFL's is designed to promote lifetime financial security for employees. It does so by deferring a portion of a player's income to his retirement years and by obligating the NFL to contribute additional funds for those same years. By implication, a pension system recognizes that employees often fail to save enough of their earnings to account for future expenses. For a number of reasons, many NFL players will eventually, and sometimes unexpectedly, rely on their pensions for sustenance.

McCann, supra note 4. See also infra note 209 and accompanying text (stating that those supporting the current Plan argue, in part, that a disability plan does not exist to provide entitlements).

14. See discussion infra Part II (examining more fully the growth and purpose of the NFLPA).

15. See discussion infra Part VI.A-C (discussing common complaints former players have about the current plan).

16. See discussion infra Part III (discussing key provisions of the current plan).

17. See infra note 55 and accompanying text (analyzing governing ERISA provisions).

18. See infra notes $95-99$ and accompanying text (discussing the Retirement Board).

19. See infra note 95 and accompanying text (discussing the Retirement Board composition).

20. See infra note 98 and accompanying text (discussing that the Retirement Board has full and absolute discretion to manage the Plan). 
Congress."21 Employing words such as "'travesty,' 'broken' and 'pitiful,' Democrats and Republicans seized upon how an industry that generates approximately $\$ 7$ billion in annual revenue paid about $\$ 20$ million in benefits to a total of 317 retirees, about $\$ 63,000$ apiece." 22 Echoing similar sentiments, numerous former NFL players took their complaints about the NFLPA directly to the White House on September 18, 2007. ${ }^{23}$ During the hearing, former Dallas Cowboys running back Daryl Johnston did not mince words, stating that "[he] discovered by going through the NFLPA Disability process $^{24}$ that [the] system was put in place to deny claims by former players." ${ }^{25}$ Therein lies the question: Does such a plan, though ostensibly in complete conformity with ERISA law ${ }^{26}$ effectively address the needs of its beneficiaries-disabled former NFL players? ${ }^{27}$

The objective of this Comment is to provide a comprehensive overview of the NFL Disability Plan (the Plan) currently in force, analyze the disability claims procedure under the Plan, and review the appeals to federal court of retired players when challenging decisions made by the Retirement Board under the Plan. Such an exercise allows one to cut through the numerous and sharply disparate opinions on the effectiveness of the current disability plan structure and arrive at practical suggestions for improvement. Part II discusses the emergence of a players association in the NFL and the beginnings of disability benefits in the league. ${ }^{28}$ Part III outlines the structure of the current Plan. ${ }^{29}$ Part IV discusses the litigation in federal

21. McCann, supra note 4.

22. Alan Schwarz, Congress Scolds N.F.L. and Union, N.Y. TIMES, June 27, 2007, available at http://www.nytimes.com/2007/06/27/sports/footbal//27nfl.html. Criticism was especially fierce from Representative Maxine Walters, a Democrat of California, who in disbelief asked, "So in one of the most dangerous sports in the history of mankind, only 317 players are receiving disability from this source-is that correct?" Id.

23. See generally Oversight Hearing, supra note 10.

24. See discussion infra Part IV.A (outlining the process of filing a disability claim).

25. Oversight Hearing, supra note 10 (statement of Dave Duerson, Trustee for the Burt Bell/Pete Rozelle Retirement Plan, and former NFL Player). Hall of Famer Gale Sayers, who spent his entire career with the Chicago Bears, concurs: "The current disability system routinely bars retired players from fair access to disability payments that offer a minimal standard of care. The word often heard is that the inconvenient 'problem' of disability will eventually pass away-a nice way of saying that the retirees themselves will conveniently die." Oversight Hearing, supra note 10 (statement of Gale Sayers, former NFL Player). See also infra note 199 and accompanying text (citing players who describe the Plan as "Delay, Deny and Hope They Die").

26. See generally 29 U.S.C. $§ § 1001-1461$ (2006); see also infra note 55 and accompanying text (discussing the objectives and purposes of ERISA).

27. At the outset it is sufficient to say that opinion is decidedly mixed, with outspoken advocates on both sides of the question. See supra note 25 and accompanying text (statement of Daryl Johnston); see also infra note 88 and accompanying text (Gene Upshaw resorting to "schoolyard taunts"); see also discussion infra Part VII.C.D (discussing retirees' dislike of Gene Upshaw).

28. See infra notes $35-53$ and accompanying text.

29. See infra notes 54-86 and accompanying text. 
court over decisions by the Retirement Board under the Plan. ${ }^{30}$ Part V analyzes the one case where a Retirement Board decision was overturned in federal court, and it then probes the far more numerous cases where the Retirement Board's decision was upheld. ${ }^{31}$ Part VI examines the perceived difficulties with the current Plan. ${ }^{32}$ Part VII presents suggestions for improving the Plan, such as improved Plan phraseology, elimination or extension of time-sensitive restrictions on full benefits, giving retired players a voice on the Retirement Board, and more effective NFLPA leadership in the collective bargaining process. ${ }^{33}$ Part VIII concludes by reasserting the need for an enhanced NFL Disability Plan that adequately provides for the needs of disabled retirees. ${ }^{34}$

\section{THE BIRTH OF THE NFLPA AND THE EVOLUTION OF NFL DISABILITY BENEFITS}

The National Football League Players Association, established in $1956,{ }^{35}$ is the union for professional football players in the NFL ${ }^{36}$ Inter alia, the NFLPA negotiates and monitors retirement benefits for all current and former players. ${ }^{37}$ Nearly forty years passed from the formation of the NFL

30. See infra notes $87-117$ and accompanying text.

31. See infra notes 118-77 and accompanying text.

32. See infra notes $178-221$ and accompanying text.

33. See infra notes $222-64$ and accompanying text.

34. See infra notes 265-73 and accompanying text.

35. Soar v. Nat'l Football League Players Ass'n, 438 F. Supp. 337, 340 (D. R.I. 1975) ("The 'NFLPA' was founded in late 1956."). The official website of the NFL Players Association details the requests made at the very first meeting of the newly birthed NFLPA: "The proposals from that initial meeting were few in number - players requested a minimum $\$ 5,000$ a year salary, uniform per diem pay for players, a rule requiring clubs to pay for players' equipment and, more importantly, $a$ provision for the continued payment of salary to an injured player." NFL Players Association, About Us: History: The Beginning-1956, http://www.nflplayers.com/user/template.aspx?fmid= $182 \& 1 \mathrm{mid}=239$ \&pid=0\&type $=$ I (last visited Mar. 25, 2009) (emphasis added). However, after the players submitted their proposal to League Commissioner Bert Bell in January 1957, the proposals were ignored by him and the owners. Id.

36. NFL Players Association, About Us: Our History, http://www.nflplayers.com/user/aboutus.aspx ?fmid=182\&lmid=182\&pid=0\&type $=1$ (last visited Mar. 25, 2009). Its official website asserts that the NFLPA "has a long history of assuring proper recognition and representation of player's interests," and "has shown that it will do whatever is necessary to assure that the rights of players are protected-including ceasing to be a union, if necessary, as it did in 1989." Id.

37. Id. Initially, the Association's primary goal was to "gain official recognition by the 'NFL" member clubs of their representational status with respect to all player-employees and thereby to obtain for the players improved working conditions, salaries, etc. and the approval of a pension plan for 'NFL' players." Soar, 438 F. Supp. at 340. Other responsibilities came to include, for example, representing players in matters dealing with wages and working conditions, and ensuring compliance 
to the unveiling of the first NFL pension plan. ${ }^{38}$ In 1959, for the first time ever, the NFLPA agreed to implement a retirement system, bringing about modest benefits for former players. ${ }^{39}$ A collective bargaining agreement was first reached in 1962, establishing the "Bert Bell ${ }^{40}$ NFL Player Retirement Plan,"41 that "provide[d] [enhanced] retirement, disability and related benefits to eligible ${ }^{42}$ former professional football players. ${ }^{, 43}$ Such plan has been dubbed the "Old Plan."

In 1989, NFL owners created the "Pete Rozelle" NFL Player Retirement Plan., ${ }^{, 46}$ Although similar to the Old Plan, it placed the power to decide matters relating to pension, disability benefits, and investing squarely in the hands of the owners. ${ }^{47}$ In 1993, a new collective bargaining agreement was reached, improving the retirement program for players. ${ }^{48}$

with the Collective Bargaining Agreement. NFL Players Association, About Us, http://www.nfl players.com/user/about-us.aspx?fmid=182\&lmid=182\&pid=0\&type=1 (last visited Mar. 25, 2009).

38. HISTORY OF RETIREMENT AND T\&P BENEFITS FOR NFL PLAYERS 1 (2007), available at http://web.archive.org/web/20070710080437/www.nflpa.org/pdfs/NewsAndEvents/History_of_the _ NFLPA\%E2\%80\%99s_Retired_Player_Benefits.pdf (last visited Mar. 25, 2009) [hereinafter HISTORY OF RETIREMENT].

39. McCann, supra note 4. Players succeeded in "push[ing] through pension coverage to a group of 110 [NFL] players who were in the league in 1959." NFL Players Association, About Us: NFLPA History: The 1960's-AFL/NFL Competition, http://www.nflplayers.com/user/template. aspx? fmid=182\&lmid=229\&pid=1033\&type=lc (last visited Mar. 25, 2009). "Life insurance and health coverage benefits were improved, and, for the first time, two player reps were designated to sit on the Retirement Board." Id.

40. The Plan's namesake, Bert Bell, "built [the NFL's] image to unprecedented heights as commissioner" from 1946-1959. Pro Football Hall of Fame: Bert Bell, Official Site of the Pro Football Hall of Fame, http://www.profootballhof.com/hof/member.jsp?player_id=23 (last visited Mar. 25, 2009).

41. HISTORY OF RETIREMENT, supra note 31 , at 4.

42. "[P]re-59er's," or players who stopped playing professional football before 1959 , were not covered by the plan and received no pension. Id. Such players were considered "the league's founding players." Id. at 5; see also infra note 49 and accompanying text (1993 Collective Bargaining Agreement expanded Plan coverage to include Pre-59er's).

43. Sweeney v. Bert Bell NFL Player Ret. Plan, 961 F. Supp. 1381, 1383 (S.D. Cal. 1997), aff'd in part, rev'd in part, 1998 WL 480125 (9th Cir. 1998) (unpublished table decision); see also McCann, supra note 4 (describing the various plans brought into existence through collective bargaining between the NFL and the NFLPA). Initially, the NFLPA "had no role in the management of this Plan." HISTORY OF RETIREMENT, supra note 31 , at 1 .

44. Sweeney, $961 \mathrm{~F}$. Supp. at 1383.

45. Pete Rozelle was the NFL's second commissioner. HISTORY OF RETIREMENT, supra note 31 , at 4 .

46. Id.

47. Id. "This was a significant change from how the original Bert Bell NFL Player Retirement Plan was managed at the time, where the union had the right to appoint three of the Plan's six voting trustees." Id. The plan did not provide for any player trustees, only for total control by the owners. Id.

48. Id. at 5. The Collective Bargaining Agreement "guarantees more than $\$ 1$ billion in pension, health, and post-career benefits for current and retired players . ..." NFL.com, NFL History by Decade 1991-2000, 1993, http:/www.nfl.com/history/chronology/1991-2000 (last visited Mar. 25, 2009). Furthermore, as a result of the agreement, 854 former players and 65 beneficiaries were 
Accordingly, the Pete Rozelle Plan merged into the Bert Bell Retirement Plan, resulting in the "Bert Bell/Pete Rozelle NFL Player Retirement Plan"49 (the Plan). ${ }^{50}$ In addition, the 1993 collective bargaining effort led to the creation of the "NFL Player Supplemental Disability Plan (Supplemental Plan). $"{ }^{51}$ As the name suggests, the Supplemental Plan provides disability benefits over and above those advanced under the Plan. ${ }^{52}$ In summation, the Plan and the Supplemental Plan are collectively called "the Plans." 53

\section{STRUCTURE OF THE PLAN UNDER ERISA}

\section{"[I]f an individual is 'employable,' he does not qualify for total and permanent disability." 54}

The NFL Plans in question are employee benefits plans covered by the Employee Retirement Income Security Act of 1974, as amended (ERISA). ${ }^{55}$

added to the Retirement Plan. NFLPA, WHITE PAPER 23 (2007), http://nflpa.org/whitepaper/ NFLPA_White_Paper.pdf (on file with author) [hereinafter NFLPA WHITE PAPER].

49. HISTORY OF RETIREMENT, supra note 31, at 5. The new agreement reduced vesting "so that going forward a player needed only three Credited Seasons to receive a pension." Id. In addition, the 1993 Collective Bargaining Agreement expanded the Plan to include the hitherto neglected "pre59er's." Id.; see supra note 42 and accompanying text (defining "pre-59er's" as those players who played professional football before 1959 and were not originally included in the Plan).

50. See Sweeney v. Bert Bell NFL Player Ret. Plan, 961 F. Supp. 1381, 1383 (S.D. Cal. 1997). Courts sometimes also refer to the Plan as the "New Plan" or the "Base Plan." Id. For purposes of this Comment, the Bert Bell/Pete Rozelle NFL Player Retirement Plan will be referred to as "the Plan."

51. McCann, supra note 4; see infra notes 52,57 and accompanying text (further describing the Supplemental Plan).

52. Sweeney, $961 \mathrm{~F}$. Supp. at 1383; see infra note 57 and accompanying text (further describing the Supplemental Plan).

53. Id. This Comment will further explain the provisions of the Plans, but the following description is sufficient for the present purpose:

The NFL enrolls all players in the Bert Bell/Pete Rozelle NFL Retirement Plan (the "Plan") and the NFL Player Supplemental Disability Plan (together, the "Plans"). .. The operative language determining eligibility for benefits is found in the Plan. The NFL Player Supplemental Disability Plan, in contrast, operates to augment the size of benefits awards after eligibility has been established under the Plan.

Jani v. Bert Bell/Pete Rozelle NFL Player Ret. Plan, 209 F. App'x 305, 306 n.1 (4th Cir. 2006) (internal citations omitted).

54. Oversight Hearing, supra note 10; see also infra note 63 and accompanying text (discussing the "employable" requirement).

55. Sweeney, 961 F. Supp. at 1383 . "The Plans are employee benefit plans covered by the Employee Retirement Income Security Act of 1974, as amended ("ERISA"), 29 U.S.C. §§ 10011461." Id. As to the statute's purpose, broadly speaking, ERISA "is a federal law that sets minimum standards for most voluntarily established pension and health plans in private industry to 
Under this statute, the Plan is considered an "employee pension benefit plan," 56 while the Supplemental Plan qualifies as an "employee welfare benefit plan."

provide protection for individuals in these plans." DOL.gov, Employment Retirement Income Security Act-ERISA, http://www.dol.gov/dol/topic/retirement/erisa.htm (last visited Mar. 25, 2009). Given that "the growth in size, scope, and numbers of employee benefit plans in recent years has been rapid and substantial . . . [ [I]t is desirable in the interests of employees and their beneficiaries, ... . that disclosure be made and safeguards be provided with respect to the establishment, operation, and administration of such plans . . ." 29 U.S.C. $\S 1001$ (2000). Moreover, as noted by the Department of Labor, ERISA generally requires the following:

ERISA requires plans to provide participants with plan information including important information about plan features and funding; . . . provides fiduciary responsibilities for those who manage and control plan assets; requires plans to establish a grievance and appeals process for participants to get benefits from their plans; [and] gives participants the right to sue for benefits and breaches of fiduciary duty.

DOL.gov, supra. Furthermore, the required features of a typical employee benefit plan are as follows:

Requisite features of plan. Every employment benefit plan shall-

(1) provide a procedure for establishing and carrying out a funding policy and method consistent with the objectives of the plan and the requirements of this subchapter,

(2) describe any procedure under the plan for the allocation of responsibilities for the operation and administration of the plan...

(3) provide a procedure for amending such plan, and for identifying the persons who have authority to amend the plan, and

(4) specify the basis on which payments are made to and from the plan.

29 U.S.C. $\S 1102$ (b) (2000).

56. See Sweeney, 961 F. Supp. at 1383 ("The New Plan is an employee pension benefit plan within the meaning of 29 U.S.C. $\$ 1002(2) . ") .29$ U.S.C. $\S 1002(2)$ provides, in pertinent part, the following:

[T] he terms "employee pension benefit plan" and "pension plan" mean any plan, fund, or program which was heretofore or is hereafter established or maintained by an employer or by an employee organization, or by both, to the extent that by its express terms or as a result of surrounding circumstances such plan, fund, or program-(i) provides retirement income to employees, or (ii) results in a deferral of income by employees for periods extending to the termination of covered employment or beyond....

29 U.S.C. $\$ 1002(2)(2000)$. Pursuant to ERISA, the "plan sponsor" would consist of the NFL and the NFLPA. See $\S 1002(16)(B)(i i i)$. The "plan sponsor" is, "in the case of a plan established or maintained ... jointly by one or more employers and one or more employee organizations, the association, committee, joint board of trustees, or other similar groups of representatives of the parties who establish or maintain the plan." Id.

57. See Sweeney, 961 F. Supp. at 1383 (classifying the New Plan and the Supplemental Plan within ERISA). "The Supplemental Plan is an employee welfare benefit plan within the meaning of 29 U.S.C. § $1002(1)$." Id. An "“employee welfare benefit plan' . . mean[s] any plan, fund, or program which ... is . . maintained by an employer" to provide for its participants "benefits in the event of . . disability." 29 U.S.C. $§ 1002$ (1) (2000). "Like the Player Retirement Plan, eligibility terms and benefit levels under the Supplemental Plan are determined through collective bargaining between the NFLPA and NFLMC and memorialized in the governing plan document." Courson v. Bert Bell NFL Player Ret. Plan, 75 F.Supp.2d 424, 429 n.2 (W.D. Pa. 1999), aff'd, 214 F.3d 136 (3d Cir. 2000). "The [Supplemental] plan is administered by a Disability Board composed of six voting members." Id.; see also supra notes 51-53 and accompanying text (further defining and explaining the parameters of the Supplemental Plan). 
upon a player's accumulated "benefit credits," benefits to eligible participants (i.e., certain active players and vested ${ }^{59}$ inactive players) who become totally and permanently disabled."

58. See Appendix, infra Exhibit 1 (detailing how benefit credits are calculated). For a season to be considered "credited," the player must be either listed as "active," "inactive injured reserve," or "physically unable to perform football" for "at least three regular-season or post-season games." NFL Players Association, Benefits Resources, http://www.nflplayers.com (follow the "Member Services" hyperlink; then follow the "Resources" hyperlink; then follow the "Benefits" hyperlink) (last visited Mar. 25, 2009); see also infra note 53 (discussing vesting requirements).

59. To be considered "vested," the player must play in the NFL at least three seasons. NFLPA WHITE PAPER, supra note 41, at 9. A player generally "earns a season if he is paid for three or more games during that season." Id. "[A] Vested Inactive Player is 'a Vested Player who is not an Active Player." Green v. Bert Bell/Pete Rozelle NFL Player Ret. Plan, No. CIV.A.3:98-CV-2235-D, 1999 WL 417925, at *2 (N.D. Tex. June 22, 1999). Beyond this general definition of "vested," however, there are several other avenues by which a former player can vest:

[A] Vested Player . . . is a player who: (a) earns five Credited Seasons; (b) earns four Credited Seasons, including a Credited Season after the 1973 Plan Year; (c) earns three Credited Seasons, including a Credited Season after the 1992 Plan Year; (d) after the 1975 Plan Year, is an Employee on his Normal Retirement Date; [or] (e) after receiving total and permanent disability benefits under Article 5, is found to no longer qualify for total and permanent disability.

$I d$. at $* 2-3$. An example of the application of such language in determining whether a player has vested is found in Green. See generally id. In Green, former player Anthony Green's application for benefits was "denied ... on the ground that he was not a Vested Inactive Player who was entitled to receive Plan benefits." Id. at *1. Green could "become a Vested Inactive Player only if he earned a sufficient number of Credited Seasons." Id. at *3. As his only NFL employment activity was during the 1990, 1991, 1992, and 1993 seasons, Green only qualifies "if he has four Credited Seasons ... or has three Credited Seasons, including at least one Credited Season after the 1992 Plan year." Id. Unfortunately for Green, the evidence in the record showed that during the 1993 season, the Seattle Seahawks waived him in the preseason and terminated his contract, and "did not make any injury-related payments to him" for the season. Id. at *4. Accordingly, as Green "failed to demonstrate that he earned a Credited Season for 1993," he did not qualify as a Vested Inactive Player. Id.

60. Sweeney, $961 \mathrm{~F}$. Supp. at 1383 (emphasis added). The key question is the definition of the term "totally and permanently disabled":

4. Under the Old Plan, in effect prior to July 1, 1993, an eligible player was "deemed to be totally and permanently disabled if the Retirement Board shall find that he has become totally disabled to the extent that he is prevented from or unable to engage in any occupation or employment or remuneration of profit."...

5. Under the New Plan, an eligible player is "deemed to be totally and permanently disabled under Article 5 if the Retirement finds that he has become totally disabled to the extent that he is substantially prevented from or substantially unable to engage in any activity for remuneration or profit.["]

Id. (emphasis added). However, the New Plan further qualifies the definition of "totally and permanently disabled":

A Player will not be considered to be able to engage in any occupation or employment for remuneration or profit ... merely because such person is employed by the League or [a member club of the League], manages personal or family investments, is employed by or associated with a charitable organization, or is employed out of benevolence. 
However, "[t]he [Plan] awards both 'total and permanent' ('T\&P') disability benefits... and partial disability benefits," which are frequently called "Line of Duty benefits," or "LOD.""1 Quite succinctly, T\&P disability benefits "are paid when an eligible player is unable to work, and are designed to replace income." 62 Thus, "if an individual is 'employable', he does not qualify for total and permanent disability." ${ }^{\text {"63 }}$ LOD benefits, in contrast, are available to players suffering from a "substantial disablement." 64

Under the Old Plan, both T\&P and LOD disability benefits were available. ${ }^{65}$ Two levels of T\&P benefits were payable under the Old Plan: "(a) a higher 'football' benefit for a disability which results from $a$ 'football' injury; ${ }^{66}$ and (b) a lower 'nonfootball' benefit for disability resulting from

Jani v. Bert Bell/Pete Rozelle NFL Player Ret. Plan, No. Civ. WDQ-04-1606, 2005 WL 1115250, at *2 (D. Md. Apr. 26, 2005) (emphasis added). Finally, "the Board has the discretion to define 'T\&P disability' in any reasonable and consistent manner." Jani v. Bert Bell/Pete Rozelle NFL Player Ret. Plan, 209 F. App'x 305, 315 (4th Cir. 2006) (citing Booth v. Wal-Mart Stores, Inc. Assocs. Health \& Welfare Plan, 201 F.3d 335, 342 (4th Cir. 2000)).

61. NFLPA WHITE PAPER, supra note 41, at 7, 9; see also supra note 38 (defining total and permanent disability).

62. NFLPA WHITE PAPER, supra note 41, at 7. "Eligible players may receive T\&P benefits even when their inability to work occurs many years after a football career has ended, and even when NFL football did not cause the inability to work." Id. at 8 . Upon reaching retirement age (fiftyfive), a retired player "will begin receiving the higher of either his disability payment or his pension for the remainder of his life." Id. As is typical among employers, those who begin receiving their pension can not apply for disability. Id.

63. Oversight Hearing, supra note 10.

64. NFLPA WHITE PAPER, supra note 41 , at 9. A rating system created by the American Medical Association is generally used for measuring whether an impairment rises to the level of "substantial." See Appendix, infra Exhibit 2 (outlining rating system as to orthopedic injuries, the most common type of NFL injury). An NFL player is eligible for LOD benefits after playing "in as little as one [NFL] game." NFLPA WHITE PAPER, supra note 41, at 8 . However, "[t]o receive 'LOD' disability a player must apply within 48 months (4 years) after his NFL career ends." Id. at 9. LOD benefits are paid for up to 7.5 years, or 90 months. Id. As to the amount a player will receive, "[a] player's LOD benefit equals the sum of his Benefit Credits. Therefore, a player who leaves the game today with five seasons would have a monthly LOD benefit of $\$ 2,350$ ( 5 seasons times $\$ 470$ )." Id.; see also Appendix, infra Exhibit 1 (defining benefit credits). The player will receive at least $\$ 1000$ per month regardless of the number of seasons he played. NFLPA WHITE PAPER, supra note 41 , at 9 .

65. See Armstrong v. Bert Bell NFL Player Ret. Plan, 646 F. Supp. 1094, 1097 (D. Colo. 1986) ("LOD benefits are governed by article 6 of the plan. ... The plan also covers total and permanent disabilities."). Armstrong provides more than just a compelling factual scenario-it is helpful in understanding the structure of the Old Plan. Plaintiff, Otis Armstrong, "injured his neck in preseason [football] drills ... [and] subsequently experienced a numbness or tingling sensation in his extremities," eventually becoming "unable to conceive of the location of his extremities in the space around him." Id at 1096. Such health difficulties subsided enough for him to resume his career, but Armstrong was later hit by a lineman during a running play and re-injured his neck such that he could no longer play football. Id.

66. Significant litigation was to ensue throughout the years over the meaning of the phrase "a football injury." See, e.g., Brumm v. Bert Bell NFL Retirement Plan, 995 F.2d 1433, 1439 (8th Cir. 1993); Washington v. Bert Bell/Pete Rozelle NFL Player Retirement Plan, 504 F.3d 818, 820 (9th 
[something] other than a football injury."67 As could be guessed, "football" level benefits exceeded benefits available for "non-football" disabilities. ${ }^{68}$ In addition, monthly LOD benefits were payable "for a player incurring a substantial disablement arising out of football activities." ${ }^{.69}$ Finally, the Old Plan reconciled the two-tiered T\&P benefits with the LOD benefits by providing that a player qualifying for $\mathrm{T} \& \mathrm{P}$ benefits was to be paid those benefits in lieu of other benefits "for any month in which [those benefits are] larger than the line-of-duty benefit." $" 70$

In contrast, under the Plan, instead of a two-tiered classification similar to the Old Plan, there are four categories of total and permanent disability benefits: Active Football, Active Non-Football, Football Degenerative, and

Cir. 2007). In Brumm, the circuit court determined that the district court erred in considering "the Board's differentiation 'between those whose disability can be traced to a single injury and those whose disability is the result of a football career's overall impact on the body, making the body more susceptible to injury later in life" "as reasonable. Brumm, 995 F.2d at 1438. The Old Plan was silent as to the meaning of "a football injury incurred while an Active Player" and did not inform potential claimants that this meant a "single, identifiable injury." Id. at 1439 . The court noted that such an interpretation did not further the goal of the Old Plan: "If the [Old] Plan's goal is to take care of the players as part of their compensation for investing themselves in the sport, players who suffer a series of football injuries resulting in disability are as entitled to consideration as those suffering a single disabling injury." Id. The court continued to say that "[i]t is hard to imagine a participant who, after reading the language in both the Plan and the summary plan description, would assume that a single, identifiable football injury was necessary in order to qualify for the higher level of benefits." Id. The court held that such a single-injury limitation would probably be "commonly invoked to deny benefits to career football players who suffer numerous and cumulative disabling injuries over the course of their careers." Id. Therefore, such an interpretation does not comply with ERISA. Id. Such an analysis was brought to bear in the recent case of former player Victor A. Washington. See generally Washington, 504 F.3d at 823-24. Washington was initially denied "football" benefits under the Old Plan because the arbitrator interpreted the phrase "'a football injury,' as requiring that a player's disability be linked to $a$ single football injury." Id. at 820 (emphasis in original). Consequently, the arbitrator had found that Washington did not identify a single injury that resulted in him having to leave the game, as he suffered knee, shoulder, elbow, and ankle injuries during his playing career. Id. at 819-20. However, the Washington court noted that, pursuant to Brumm, the system "was meant to be a football versus non-football distinction rather than the single injury versus multiple or cumulative injury construction . . . " Id. at 820 . "To require that disability result from a single, identifiable football injury when the relevant Plan language speaks of 'a football injury incurred while an Active player' is to place undue and inappropriate emphasis on the word "a." Id. at 820-21. In summary, then, "a football injury" refers to a either a single injury or the result of a cumulative series of injuries. Id. at 821 .

67. Sweeney v. Bert Bell NFL Player Ret. Plan, 961 F. Supp. 1381, 1383 (S.D. Cal. 1997); see also Washington v. Bert Bell/Pete Rozelle NFL Player Retirement Plan, 504 F.3d 818, 820 n.2 (9th Cir. 2007).

68. Washington, 504 F.3d at 820 .

69. Armstrong, 646 F. Supp. at 1097; see also supra note 41 (definition of substantial disablement). LOD benefits were payable for up to sixty months. Armstrong, 646 F. Supp. at 1097.

70. Armstrong, 646 F. Supp. at 1097 n.1. 
Inactive. ${ }^{71}$ An "Active Football" disability "results from League football activities, arises while the Player is an Active Player, and causes the Player to be totally and permanently disabled 'shortly after' ${ }^{72}$ the disability first arises." ${ }^{\text {"73 }}$ Such a classification can be remembered by the phrase "Footballrelated, within six months" in that "[a] former player receives $\$ 224,000$ per year if he becomes totally and permanently disabled due to NFL football within six months after his NFL career ends." ${ }^{.74}$ The second classification, "Active Non-Football," can be succinctly summarized by the phrase "Nonfootball related, within six months." Football "receives $\$ 134,000$ per year if he becomes totally and permanently disabled from any other cause within six months after his NFL career ends." The third category is "Football Degenerative." $" 77$ Benefits under this category are labeled "Football-related, within fifteen years" as "a former player receives $\$ 110,000$ a year if he becomes totally and permanently disabled due to NFL football within 15 years after his NFL career ends."

71. NFLPA WHITE PAPER, supra note 41 , at 8.

72. The phrase "shortly after" is certainly vague. Accordingly, the Plan further defines the term. To give an example:

An applicant becomes T \& P disabled "shortly after" the disability first arises for purposes of the definition of Active Football benefits according to a three-tiered scheme of presumptions: A player who becomes totally and permanently disabled no later than six months after a disability(ies) first arises . . . and a Player who becomes totally and permanently disabled more than 12 months after a disability(ies) first arises will be conclusively deemed not to have become totally and permanently disabled "shortly after" the disability(ies) first arises .... In cases falling within this six-to twelve-month period, the Retirement Board will have the right and duty to determine whether the "shortly after" standard is satisfied.

Jani v. Bert Bell/Pete Rozelle NFL Player Ret. Plan, 209 F. App'x 305, 309 (4th Cir. 2006).

73. Sweeney v. Bert Bell NFL Player Ret. Plan, 961 F. Supp. 1381, 1384 (S.D. Cal. 1997) (emphasis added). Under "Active Football" T\&P disability, "[t]he monthly total and permanent disability benefit will be no less than $\$ 4,000$." Id. Vesting is not required because Active Football benefits are available to a player who plays in as little as one NFL game. Id.

74. NFLPA WHITE PAPER, supra note 41 , at 8.

75. Id.

76. Id. The monetary amount could be higher based upon a player's benefit credits. Moreover, no vesting is required to take under this category; Active Non-Football benefits are "available to a player who plays in as little as one game." Id.

77. Id.

78. Id. Interestingly, such figures appear to contradict the descriptions provided to the court in Jani v. Bert Bell/Pete Rozelle NFL Player Ret. Plan, 209 F. App'x 305 (4th Cir. 2006). There, the court characterized "Football Degenerative" as "[a] lesser benefit . . . available provided that "the disability(ies) arises out of League football activities, and results in total and permanent disability before the later of (1) age 45, or (2) 12 years after the end of the Player's last Credited Season." Id. at 308. Nonetheless, it is critical to examine the phrase "arising out of League football activities" as it holds relevance for all four classifications under the Plan. See Boyd v. Bert Bell/Pete Rozelle NFL Players Ret. Plan, 410 F.3d 1173, 1177 (9th Cir. 2005). The Plan definition of "Arising out of League football activities" is as follows:

[A] disablement arising out of any League pre-season, regular-season, or post-season game, or any combination thereof, or out of League football activity supervised by an 
Finally, a former player can qualify for T\&P benefits under the fourth category, "Inactive." The no time limit" in that a player who qualifies "receives a minimum of $\$ 18,000$ a year ... if he becomes totally and permanently disabled and does not qualify for one of the other categories." related" benefits, ${ }^{81}$ the cause of total disability must be "such that, if the football related injury did not exist, the participant would not be totally disabled." $" 82$

Employer, including all required or directed activities. 'Arising out of League football activities' does not include, without limitation, any disablement resulting from other employment, or athletic activity for recreational purposes, nor does it include a disablement that would not qualify for benefits but for an injury (or injuries) or illness that arises out of other than League football activities.

Id. at 1177 n.3.

79. NFLPA WHITE PAPER, supra note 41 , at 8.

80. Id. at 8-9. The amount of the payout can be higher based upon a player's benefit credits. Id. at 9. The amount of the yearly payment rises to $\$ 21,000$ for applications on and after April 1, 2007 . Id. at 8 .

81. See supra notes $73-74,77-78$ and accompanying text (defining Active Football and Football Degenerative benefits).

82. Webster v. Bert Bell/Pete Rozelle NFL, Player Ret. Plan, No. 96-21130, 1997 WL 680852, at *1 (5th Cir. Sept. 22, 1997) (emphasis added). In Webster, the Fifth Circuit held:

[T] The Retirement Board did not abuse its discretion in denying [George] Webster football benefits ... [as his] medical records contain ample evidence that he first became totally disabled as a result of throat cancer, as well as other nonfootball related injuries, and that they continued to plague him throughout the time he sought football benefits ....

Id.; see also infra notes 93-95 and accompanying text (discussing the Retirement Board) and note 110 and accompanying text (elaborating upon the abuse of discretion standard). To be eligible for football-related benefits, one must establish total and permanent disability "solely as a result of football related injuries." Webster, 1997 WL 68052, at * 1 . In other words, the Retirement Board will not abuse its discretion in denying football-related benefits because "the initial and continuing cause of ... total disability was unrelated to football." Id. To be eligible for Active Football and Football Degenerative benefits, the totally disability must result "from a football injury." Id. A plausible and reasonable interpretation of the Plan "permit[s] football benefits only if total disability would not exist but for the presence of football related injuries." Id. Webster's non-football related injuries were totally disabling, so the appellate court had no difficulty affirming the judgment of the district court in favor of the Plan. Id. In a similar vein to Webster, the court in Youso v. Bert Bell NFL Retirement Plan affirmed the district court's grant of summary judgment in favor of the Plan. No. 98-1914, 2000 WL 1670886, at *1 (8th Cir. Jan. 5, 1998). While "[t]here was some evidence that the trauma Youso suffered while playing football contributed to the severity of his disability," the Plan's decision to deny football-related benefits was reasonable in that they determined that his "lower back condition was not the result of a football injury." Id. Youso played football from 1958 to 1965 , and contended "the disability was the result of injuries he had sustained while playing football." Id. However, "[i]n 1980, he fell down a flight of stairs and suffered a lower back injury that proved to be totally disabling." Id.; cf. Jani, 209 F. App'x at 310-11 (applicant eligible for football-related benefits because of medical evidence establishing that applicant's total and permanent disability arose solely from football activities). 
With regard to the New Plan, an important qualification to keep in mind is a provision imposed that may bar otherwise eligible former players from recovering certain $T \& P$ benefits for periods of time more than 42 months prior to when the player first submits a written application to the Plan Director requesting benefits. ${ }^{83}$ However, such limitations period "will be tolled for any period of time during which such Player is found by the Retirement Board to be physically or mentally incapacitated in a manner that substantially interferes with the filing of such claim." 84 Stated differently, the provision "disallows establishment of an onset date for T \& P disability earlier than 42 months prior to the filing of the application, unless the applicant's mental incapacity substantially interfered with the filing of the claim." ${ }^{\prime 85}$ Moreover, a 1998 amendment to the Plan was made to specifically address the awarding of disability benefits for head injuries, among other illnesses. ${ }^{86}$

83. Jani, 209 F. App'x at 309. The ostensible purpose of such a provision is both to encourage the prompt filing of claims and to discourage fraudulent claims. The court elaborates on this provision:

Even if an applicant otherwise would succeed in earning Active Football or Football Degenerative benefits from the onset date of his $T$ \& $P$ disability, a limitations provision, added to the Plan and effective for claims received on and after November 1, 1998, may prevent [a player] from recovering certain time-barred benefits. "Specifically: [N]o total and permanent disability benefit ... will be payable with respect to any month or other period of time that precedes by more than forty-two (42) months the date the Plan Director first receives a written application or similar letter requesting such benefit, provided that such written application or similar letter begins the administrative process that results in the award of the benefit."

Id. (brackets in original) (quoting Plan $\S 5.7$ ).

84. Id. at 309-10 (quoting Plan § 5.7).

85. Id. at 312 .

86. See Boyd v. Bert Bell/Pete Rozelle NFL Players Ret. Plan, 410 F.3d 1173, 1176 (9th Cir. 2005) ("[T]he Plan was amended in 1998 . . , which limits the recovery of disability benefits as a result of psychological/psychiatric disorders but provides: [A] total and permanent disability as a result of a psychological/psychiatric disorder may be awarded under [inter alia, the Football Degenerative category] if the requirements for a total and permanent disability are otherwise met and the psychological/psychiatric disorder either (1) is caused by or relates to a head injury (or injuries) sustained by a Player arising out of League football activities (e.g., repetitive concussions); (2) is caused by or relates to the use of a substance prescribed by a licensed physician for an injury (or injuries) or illness sustained by a Player arising out of League football activities; or (3) is caused by an injury (or injuries) or illness that qualified the Player for total and permanent disability benefits ...."). Such an amendment appears to be in recognition of what is a growing consensus that debilitating brain injuries are prevalent among former football players. See supra note 1 and accompanying text (football likened to violent video games); see also infra notes 191-195 and accompanying text (discussing extent of concussion injuries in the NFL). 


\section{FILING A DisabiLITY Claim}

\section{A. The Process Itself}

A player seeking disability benefits under the Plan starts by completing a written application. ${ }^{87}$ Under the Plan, Roger Goodell, Commissioner of the NFL, and Gene Upshaw, Executive Director of the NFLPA, ${ }^{88}$ do not decide disability claims. ${ }^{89}$ Rather, after completing the application, the player must then be examined by a neutral, qualified physician approved by the Retirement Board. ${ }^{90}$ After the first medical examination, an initial decision is made by the two-person "Disability Initial Claims Committee" (Committee). ${ }^{91}$ The Committee reviews the totality of the player's file and,

87. NFLPA WhITE PAPER, supra note 41, at 10. The Plan Office is located in Baltimore, and forms can either be requested by a toll-free telephone call or downloaded on the internet. See id. As simple as such a process seems, even completing a written application can be a difficult task for some applicants, which in some cases has been argued as evidence of the applicant's total and permanent disability as of the time of filling out the initial application. See infra note 132 and accompanying text (discussing Mike Webster's difficulties in completing an initial application, and the court's later finding that he was totally and permanently disabled during that period).

88. Quite interesting to note is the fierce verbal battle over the disability system that has ensued between Upshaw and several former NFL players via the news media. Upshaw has "responded to his critics with schoolyard taunts, calling [Mike] Ditka too 'dumb' to understand the issue and threatening to break [former NFL player Joe] DeLamielleure's neck." Solotaroff, supra note 1. Former player Brent Boyd says that "in Upshaw [the NFL] has the perfect stooge." Id. Mike Ditka goes even farther in his comments, stating that "[i]t's criminal. There's so much money in this goddamn game, and no one gives a shit about these guys. Bill Forrester's attached to a feeding tube,.. and here's this Upshaw, with his $\$ 6.7$ million salary, saying there's no dough left to help them out. That's greed talking ...." Id. When asked whether he reads the harsh words from former NFL players seeking improved benefits, Upshaw was quite combative and had the following to say: "'Guess what, I've been reading it, and guess what, it doesn't have any effect on what I will do tomorrow, the next day and the next hour. It's just like water off a duck's back. It had no effect before and it will have no effect." Mike Sando, Upshaw: NFLPA Won't Take From Current Pensions to Help Ex-Players, ESPN.COM, Jan. 31, 2008, http://sports.espn.go.com/nfl/news/story?id $=3225087$. Such comments are ostensibly aimed at the efforts of Mike Ditka to start "The Gridiron Greats," an organization by several former players "established to provide financial assistance and coordination of social services to retired players who are in dire need due to a variety of reasons including inadequate disability and/or pensions." Gridiron Greats, About the Gridiron Greats Fund, http://gridirongreats.org/aboutthefund.html (last visited Mar. 25, 2009).

89. Oversight Hearing, supra note 10.

90. NFLPA WHITE PAPER, supra note 41, at 10. The NFLPA describes the physician as follows:

These physicians are called neutral physicians because they are appointed jointly by the

Retirement Board members appointed by the Players Association and the NFL. Based on his examination, the physician provides a written report that describes the player's condition, measures impairments for purposes of LOD benefits, and addresses the player's ability to work.

Id. However, the neutrality of such physicians used is certainly a point of contention. Daryl Johnston elaborates: 
if it approves the application, disability payments are immediately dispensed. ${ }^{92}$ In the event the Committee denies the claim or deadlocks, "the player may appeal to the full Retirement Board for a complete review of the claim" for benefits. ${ }^{93}$ Such an appeal to the Retirement Board triggers a mandatory second trip to one or more additional neutral physicians. ${ }^{94}$

The doctor I met with is considered a neutral physician but, in reality, he was a physician designated by the NFLPA. I was not allowed to bring in x-rays, MRI's, and the doctor could not consult with the trainers from my team or the doctor who performed my surgery. He denied my claim. His only interest was whether I was capable of holding another job [for purposes of determining whether Johnston met the definition of T\&P disability]. He showed little interest in my physical condition and the injuries sustained from an 11 year NFL career. Upon appeal, to another designated NFLPA physician, my claim was denied as I walked into the office. He did not examine me, nor did he interview me. My impression was the decision was made long before I walked through the door. I am not the first to have experienced this routine treatment of injured players.

Oversight Hearing, supra note 10 (statement of Daryl Johnston, former NFL Player) (emphasis added).

91. NFLPA WHITE PAPER, supra note 41 , at 10 . "It is comprised of two individuals-one appointed by the NFL and the other by the NFLPA." Id. Mike Ditka views the Committee as problematic: "All claims are reviewed by two office staff who possess no relevant skills for reviewing disability claims." Oversight Hearing, supra note 10 (statement of Mike Ditka, former ESPN Sports Broadcaster, NFL Hall of Fame Player, and former Head Coach). Even Roger Goodell acknowledges that this additional roadblock in the application process adds to the "red tape' and the complexity of the application process." Id. (statement of Roger Goodell, Comm'r, National Football League). In fact, at the time new regulations were adopted in 2002 by the Department of Labor requiring such a Committee, the NFL "filed comments with the Department noting that these regulations would likely have the effect of slowing down decisions on disability claims, and urged that they not be adopted." Id. In Goodell's view, such requirements "have had the unintended consequence of making the application process longer and more complex, as [the NFL] feared at the time they were proposed." Id. With respect to the Committee, it appears that the NFL's hands are, at least for the moment, tied.

92. NFLPA WHITE PAPER, supra note 41, at 10. The player's file includes "all medical reports by the Plan neutral physicians and by other physicians submitted by the Player." Id.; see also supra note 91 and accompanying text (discussing complaints by both retirees and the NFLPA about the Committee).

93. NFLPA WhITE PAPER, supra note 41, at 10-11. A deadlock by the Committee results in denial of the application. Id . at 10. "[E]very employee benefit plan shall . . afford a reasonable opportunity to any participant whose claim for benefits has been denied for a full and fair review by the appropriate named fiduciary of the decision denying the claim." 29 U.S.C. $\$ 1133(2)$ (2000). "On appeal, the Retirement Board will review all available materials, whether or not presented to the Committee, and will give no deference to the decision of the Committee. The Retirement Board conducts a full and fair and totally independent review of all appeals." NFLPA WHITE PAPER, supra note 41 , at 11. Quite simply, "[a] plan administrator generally makes two determinations when deciding whether to pay benefits under an ERISA plan: (1) it resolves the facts that underlie the claim for benefits, and (2) it determines whether those facts constitute a claim to be honored under the terms of the plan." Green v. Bert Bell/Pete Rozelle NFL Player Ret. Plan, No. CIV.A.3:98-CV2235-D, 1999 WL 417925, at *1 (N.D. Tex. June 22, 1999). Should the Retirement Board decide to deny benefits, pursuant to ERISA, the Plan must "provide adequate notice in writing to any participant or beneficiary whose claim for benefits under the plan has been denied, setting forth the specific reasons for such denial, written in a manner calculated to be understood by the participant ...." 29 U.S.C. $§ 1133(1)$. Consequently, Plan administrators are "obligated to briefly state the facts of the case and the rationale for their decision. In this way, the [administrators] may begin to build up a body of precedent that will ultimately bring about a form of consistency

\section{8}




\section{B. Discretion Given to the Retirement Board}

\section{The Retirement Board consists of six voting members-three appointed by the NFL and three appointed by the NFLPA. ${ }^{95}$ Such members, though}

otherwise lacking in the administration of the Fund." Richardson v. Cent. States, SE \& SW Areas Pension Fund, 645 F.2d 660, 664 (8th Cir. 1981). "Bald-faced conclusions do not satisfy this requirement." Id. at 665 . For example, a notice letter stating that the applicant was denied benefits "because [he] did not meet the requirements of Section 5.1 of the Plan ... [in that] the disability results from a football injury incurred while an Active Player" would not be sufficient. See Brumm v. Bert Bell NFL Retirement Plan, 995 F.2d 1433, 1436 (8th Cir. 1993).

94. See NFLPA WhITE PAPER, supra note 41 , at 11 ("On appeal, the player is sent, as required by federal law, to one or more new neutral physicians for additional medical examination. These physicians provide written reports on the Player's condition."). This second batch of neutral physicians is not viewed as unbiased in the eyes of some former players. See supra note 90 and accompanying text (giving Daryl Johnston's opinion on the neutrality of the physician he visited after appealing to the Retirement Board).

95. NFLPA WHITE PAPER, supra note 41, at 11 . In addition, as Michael McCann points out, Gene Upshaw "is only elected by current players, not former players." McCann, supra note 4; see also infra note 243 and accompanying text (Upshaw is keenly aware that he is not elected by former players). Consequently, since the Retirement Board representatives are appointed by the NFL and the NFLPA, "[t]here is no one on the board looking out for the interests of former players." Oversight Hearing, supra note 10 (statement of Daryl Johnston, former NFL Player). Since Upshaw selects the three NFLPA representatives to the Retirement Board, there has been an outcry to let retired players select their own advocates to the Retirement Board as well. Id. (statement of Brent Boyd, former NFL Player). "The framework must include a designated group of retirees from each decade of the NFL in order to provide a voice for forgotten players." Id. (statement of Daryl Johnston, former NFL Player); see also discussion infra Part VII.C (explaining how retirees want a voice on the Retirement Board). The NFL-appointed voting members are the following: William Bidwill, Owner of the Arizona Cardinals; Clark Hunt, Owner of the Kansas City Chiefs; and Dick Cass, President of the Baltimore Ravens. NFLPA WHITE PAPER, supra note 41 , at 11 . The three NFLPA-appointed voting members, Tom Condon, Jeff Van Note, and David Duerson, are all retired football players. Id. Condon and Van Note both served as President of the NFLPA while active players. Id. Critics charge that these three are "all compromised in one way or another" and have even gone so far as to level ad hominem attacks on Upshaw's appointees:

One, Tom Condon, is Upshaw's agent, who negotiated his salary as the head of the union, a sum that wildly exceeds what union chiefs make in other sports. . . A second is Jeff Van Note, a broadcaster for the Atlanta Falcons, whose salary is paid by team owner Arthur Blank. The third is Dave Duerson, who pled guilty to beating his wife and throwing her out a hotel door and into a wall.

Solotaroff, supra note 1. Gale Sayers seconds such a charge in saying that "there are inherent conflicts of interest among members of [the] Retirement Board in favor of the owners of the NFL teams and active players." Oversight Hearing, supra note 10 (statement of Gale Sayers, former NFL Player). A conflict of interest could arise in that owners of NFL teams "recognize that denying benefits to the disabled retired players will minimize future contributions to the Plan by the NFL teams." Id. Interestingly, a potential conflict of interest could be a factor a court would weigh in deciding whether a decision by the Retirement Board constitutes an abuse of discretion. See Smith v. Cont'l Cas. Co., 369 F.3d 412, 417 (4th Cir. 2004) ("Where, however, an administrator or fiduciary with discretion is operating under a conflict of interest such that its decision to award or deny benefits impacts its own financial interests, as here, that conflict must be weighed as a factor in determining whether there is an abuse of discretion.") (citing Bernstein v. CapitalCare, Inc., 70 F.3d 
unpaid ${ }^{96}$ have formidable authority; the Plan came about through collective bargaining and confers to the Retirement Board the "full discretion to adjudicate claims and interpret the Plan. ${ }^{, 97}$ In other words, when deciding a former player's claim, "[t]he Plans grant the Board full and absolute discretion, authority and power to interpret ... the Plan. ${ }^{198}$ Indeed, under ERISA, such members are considered Plan fiduciaries because they exercise a measure of discretion and control over the disposition of Plan assets. ${ }^{99}$

783, 787 (4th Cir. 1995)). The Smith court provides a fuller explanation:

[W] hen a fiduciary exercises discretion in interpreting a disputed term of the contract where one interpretation will further the financial interests of the fiduciary, [a court] will not act as deferentially as would otherwise be appropriate. Rather, [a court] will review the merits of the interpretation to determine whether it is consistent with an exercise of discretion by a fiduciary acting free of the interests that conflict with those of the beneficiaries. In short, the fiduciary decision will be entitled to some deference, but this deference will be lessened to the degree necessary to neutralize any untoward influence resulting from the conflict.

Id. at 417-18 (quoting Doe v. Group Hospitalization and Med. Servs., 3 F.3d 80, 87 (4th Cir. 1993)). "The more incentive for the administrator or fiduciary to benefit itself by a certain interpretation of benefit eligibility or other plan terms, the more objectively reasonable [their] . . decision must be and the more substantial the evidence must be to support it." Id. at 418 (quoting Ellis v. Metro Life. Ins. Co., 126 F.3d 228, 233 (4th Cir. 1997)). In Bernstein, appellant argued that "the district court should have reviewed CapitalCare's decision under a lessened deferential standard because CapitalCare both insured and administered the plan and was thus operating under a conflict of interest." Bernstein, 70 F.3d at 788 . Consequently, by denying health benefit claims to its members, it would profit "by the amount of expenses avoided." Id. Such a "modified abuse of discretion standard" could lead to a slightly stricter standard being imposed on the Retirement Board's decision to deny benefits. See Smith, 369 F.3d at 418; see also infra notes 110-115 and accompanying text (discussing the deferential abuse of discretion standard). On the other hand, the counterargument is made that "the NFL employers' contributions are fixed, such contributions are held by a separate Trustee, and the funds may only be used for the exclusive benefit of players and their beneficiaries or for the payment of expenses of the plan." Courson v. Bert Bell NFL Player Ret. Plan, 75 F. Supp. 2d 424, 431 (W.D. Pa. 1999). The Courson court, while acknowledging the potential for a conflict of interest, found "there is no conflict . . . which requires special attention or a more stringent standard of review." Id. Such a conflict was "conjectural." Id.

96. Boyd v. Bert Bell/Pete Rozelle NFL Players Ret. Plan, 410 F.3d 1173, 1175 (9th Cir. 2005) ("The members of the Board serve without pay.").

97. Id. at 1178; see also supra note 95 and accompanying text (defining and analyzing the Retirement Board).

98. Jani v. Bert Bell/Pete Rozelle NFL Player Ret. Plan, 209 F. App'x 305, 313 (4th Cir. 2006) (internal quotations omitted); see also Courson, 75 F. Supp. at 428 ("[The] Retirement Board[] will have full and absolute discretion, authority and power to interpret, control, implement, and manage the Plan and Trust."). This is critical because it affects a court's standard of review: "[A] denial of benefits . . . is to be reviewed under a de novo standard unless the benefit plan gives the administrator or fiduciary discretionary authority to determine eligibility for benefits or to construe the terms of the plan." Firestone Tire \& Rubber Co. v. Bruch, 489 U.S. 101, 115 (1989) (emphasis added); see also Gallagher v. Reliance Standard Life Ins. Co., 305 F.3d 264, 268 (4th Cir. 2002) ("The plan's intention to confer discretion on the plan administrator or fiduciary ... must be clear."). "Final authority to make eligibility determinations is not delegated by the mere fact that a plan requires a determination of eligibility or entitlement by the administrator, or requires proof or satisfactory proof of the applicant's claim, or requires both a determination and proof . . ." Id. at 270 n.6 (internal citations omitted).

99. 29 U.S.C. $\S 1002(21)($ A) defines a plan "fiduciary": 
Given such power, an ERISA fiduciary has the obligation to both protect Plan assets from improper claims and pay valid claims. ${ }^{100}$ When evaluating an applicant's claimed disability benefit, the Retirement Board "must [fundamentally] decide three questions: whether someone is truly disabled (cannot work) ${ }^{101}$ whether the disability was football-related; ${ }^{102}$ and when the disability occurred." 103 Should the Retirement Board deadlock in making such a determination, the claim is either decided by a Medical Advisory Physician ${ }^{104}$ or, in rare cases, by arbitration. ${ }^{105}$

\section{Federal Court Appeal}

\section{Civil Action under ERISA}

Should a former player remain dissatisfied with the outcome of his application, under ERISA, "[a] civil action may be brought... by a

[A] person is a fiduciary with respect to a plan to the extent (i) he exercises any discretionary authority or discretionary control respecting management of such plan or exercises any authority or control respecting management or disposition of its assets, ... or (iii) he has any discretionary authority or discretionary responsibility in the administration of such Plan.

29 U.S.C. $\S 1002(21)(A)($ i), (iii) (2000).

100. Boyd, 410 F.3d at 1178 (citing Brogan v. Holland, 105 F.3d 158, 164 (4th Cir. 1997)).

101. See supra note 63 and accompanying text (explaining that someone who is employable does not meet the definition of total and permanent disability).

102. See supra note 82 and accompanying text (discussing the rationale for the Retirement Board's reasonable denial of benefits in the Webster and Youso cases).

103. NFLPA, SEPT. 18 PRESS RELEASE 3 (2007), http://nflpa.org/whitepaper/Sept_18_Press_ Release.pdf (on file with author).

104. See NFLPA WHITE PAPER, supra note 41, at 11-12. The NFLPA elaborates on the role of a MAP:

If the dispute is over a medical issue, such as whether a player medically is substantially unable to work, either side (the player-appointed trustees or the management-appointed trustees) can send the player to one of the Plan's top, pre-approved, neutral three doctors. ... [T]heir medical decisions are binding on the Retirement Board. This final review will almost always resolve any deadlock between voting trustees.

Id. (emphasis added). However, in the eyes of those claimants in disagreement with the decision of the Retirement Board, such a mechanism is largely irrelevant as the "six-member board votes unanimously almost every time." Oversight Hearing, supra note 10 (statement of Daryl Johnston, former NFL Player). Roger Goodell states that "[w]here claims are appealed to the Retirement Board, ... . [t] $]$ he Board seldom splits in its votes." Id. (statement of Roger Goodell, Comm'r, National Football League).

105. NFLPA WHITE PAPER, supra note 41, at 11-12. The NFLPA's perspective on arbitration as a means of deciding Retirement Board deadlocks is as follows: "In rare cases-and this has happened only once in the last 14 years - the deadlock is resolved by arbitration between the members of the Retirement Board." Id. at 11. 
participant or beneficiary ... to recover benefits due to him under the terms of his plan, to enforce his rights under the terms of the plan, or to clarify his rights to future benefits under the terms of the plan." ${ }^{106}$ Moreover, available relief includes equitable remedies such as an injunction, declaratory relief, and specific performance. ${ }^{107}$ The particular employee benefit plan is the entity named in the lawsuit (in this discussion, the defendant), not the Retirement Board. ${ }^{108}$

\section{Deferential Standard of Review}

Since the Plans grant the Retirement Board such considerable discretion to interpret the Plan, ${ }^{109}$ upon an applicant's appeal, federal district courts review a decision by the Retirement Board "under the deferential abuse of discretion standard rather than de novo." 110 Accordingly, "[u]nder the abuse

106. 29 U.S.C. $\S 1132$ (a) (2000). Subsection (a) addresses the subject of "[p]ersons empowered to bring a civil action." Id; see also Green v. Bert Bell/Pete Rozelle NFL Player Ret. Plan, No. CIV.A.3:98-CV-2235-D, 1999 WL 417925, at *1 (N.D. Tex. June 22, 1999) ("A plan participant or beneficiary who is denied benefits under an ERISA plan may sue to recover those benefits.").

107. §1132(a) provides:

Persons empowered to bring a civil action. A civil action may be brought ... (3) by a participant, beneficiary, or fiduciary (A) to enjoin any act or practice which violates any provision of this subchapter or the terms of the plan, or (B) to obtain other appropriate equitable relief (i) to redress such violations or (ii) to enforce any provisions of this subchapter or the terms of the plan.

Id. In bringing such a claim, "the district courts of the United States shall have exclusive jurisdiction of civil actions under [ERISA] brought . . . by a participant." $\$ 1132(\mathrm{e})(1)$.

108. $§ 1132$ (d) deals with the "[s]tatus of employee benefit plan as entity":

(1) An employee benefit plan may sue or be sued under this subchapter as an entity. Service of summons, subpoena, or other legal process of a court upon a trustee or an administrator of an employee benefit plan in his capacity as such shall constitute service upon the employee benefit plan. ... (2) Any money judgment under this subchapter against an employee benefit plan shall be enforceable only against the plan as an entity and shall not be enforceable against any other person unless liability against such person is established in his individual capacity under this subchapter.

$\S 1132$ (d)(1)-(2) (emphasis added). An example of the procedural effect of this statute can be found when the court notes in Jani that "[b]ecause the Plans, not the Board, are the Defendants in this case, we refer to the Board when discussing Webster's application process and to the Plans when discussing party actions during litigation." Jani v. Bert Bell/Pete Rozelle NFL Player Ret. Plan, 209 F. App'x 305, 306. n.2 (4th Cir. 2006).

109. See supra note 98 and accompanying text (stating that the Retirement Board is given full discretion to adjudicate claims and interpret the Plan).

110. Jani, 209 F. App'x at 313; see also Green, 1999 WL 417925, at *2 ("This court reviews a plan administrator's fact findings for abuse of discretion."). "It is well-established that a court reviewing the denial of disability benefits under ERISA initially must decide whether a benefit plan's language grants the administrator or fiduciary discretion to determine the claimant's eligibility for benefits, and if so, whether the administrator acted within the scope of that discretion." Gallagher v. Reliance Standard Life Ins. Co., 305 F.3d 264, 268 (4th Cir. 2002). "Where discretion is conferred upon the trustee with respect to the exercise of a power, its exercise is not subject to control by the court except to prevent an abuse by the trustee of his discretion." Firestone Tire \& Rubber Co. v. Bruch, 489 U.S. 101, 111 (1989) (internal citations omitted). "Under that standard, 
of discretion standard, the plan administrator's ${ }^{111}$ decision is reasonable if it is the result of a deliberate, principled reasoning process and if it is supported by substantial evidence." 112 Pursuant to ERISA, "even decisions

the Board's decision will stand unless it is without reason, unsupported by substantial evidence or erroneous as a matter of law." Youso v. Bert Bell NFL Ret. Plan, 242 F.3d 379, 379 (8th Cir. 1998). Therefore, at the appellate level, the circuit court will "review de novo the district court's application of the deferential standard of review." Id. (citing Farley v. Ark. Blue Cross \& Blue Shield, 147 F.3d 774, 777 (8th Cir. 1998)). Under such a standard, "a trustee's discretionary decision will not be disturbed if reasonable, even if the court itself would have reached a different conclusion." Booth $v$. Wal-Mart Stores, Inc. Assocs. Health \& Welfare Plan, 201 F.3d 335, 341 (4th Cir. 2000). The "court's inquiry is whether [the Retirement Board's] interpretation [of the Plan] was unreasonable." Sweeney v. Bert Bell NFL Player Ret. Plan, 156 F.3d 1238, 1238 (9th Cir. 1998) (unpublished). On the other hand, "[a] plan administrator's decision will be afforded less deference if a claimant presents 'material probative evidence demonstrating that (1) a palpable conflict of interest or a serious procedural irregularity existed, which (2) caused a serious breach of the plan administrator's fiduciary duty to [the claimant]."' Anderson v. U.S. Bancorp, 484 F.3d 1027, 1032 (8th Cir. 2007) (quoting Woo v. Deluxe Corp., 144 F.3d 1157, 1160 (8th Cir. 1998)). Moreover, a plaintiff must "show that the conflict or procedural irregularity has "some connection to the substantive decision reached." Id. (quoting Buttram v. Cent. States, S.E. \& S.W. Areas Health \& Welfare Fund, 76 F.3d 896, 901 (8th Cir. 1996)). Unfortunately for the plaintiff, however, such a showing "presents a considerable hurdle." Id. (quoting Barnhart v. UNUM Life Ins. Co. of Am., 179 F.3d 583, 588 n.9 (8th Cir. 1999)); see also supra note 95 and accompanying text (discussing the abuse of discretion standard).

111. Under ERISA, the term "administrator" means "the person specifically so designated by the terms of the instrument under which the plan is operated." 29 U.S.C. $\$ 1002(16)(A)(i)(2000)$. "An ERISA administrator abuses its discretion only if it (1) renders a decision without explanation, (2) construes provisions of the plan in a way that conflicts with the plain language of the plan, or (3) relies on clearly erroneous findings of fact." Boyd v. Bert Bell/Pete Rozelle NFL Players Ret. Plan, 410 F.3d 1173, 1178 (9th Cir. 2005) (citing Bendixen v. Standard Ins. Co., 185 F.3d 939, 944 (9th Cir. 1999); Atwood v. Newmont Gold Co., 45 F.3d 1317, 1323-24 (9th Cir. 1995)). The Boyd court goes on to note that "[a] finding is 'clearly erroneous' when although there is evidence to support it, the reviewing [body] on the entire evidence is left with the definite and firm conviction that a mistake has been committed." Id. (quoting Concrete Pipe \& Prods., Inc. v. Constr. Laborers Pension Trust, 508 U.S. 602, 622 (1993)).

112. Smith v. Cont'l Cas. Co., 369 F.3d 412, 417 (4th Cir. 2004) (citing Bernstein v. CapitalCare, Inc., 70 F.3d 783, 788 (4th Cir. 1995)). The court in Booth elaborates on factors a court may consider in its determination of whether a fiduciary abused its discretion:

(1) the language of the plan; (2) the purposes and goals of the plan; (3) the adequacy of the materials considered to make the decision and the degree to which they support it; (4) whether the fiduciary's interpretation was consistent with other provisions in the plan and with earlier interpretations of the plan; (5) whether the decisionmaking process was reasoned and principled; (6) whether the decision was consistent with the procedural and substantive requirements of ERISA; (7) any external standard relevant to the exercise of discretion; and (8) the fiduciary's motives and any conflict of interest it may have.

Booth, 201 F.3d at 342-43. "It is not an abuse of discretion for a plan fiduciary to deny benefits when it is presented with conflicting medical evidence." Jani v. Bert Bell/Pete Rozelle NFL Player Ret. Plan, No. Civ. WDQ-04-1606, 2005 WL 1115250, at *6 (D. Md. Apr. 26, 2005) (citing Elliott v. Sara Lee Corp., 190 F.3d 601, 606 (4th Cir. 1999)). However, "the conflicting evidence on which the fiduciary relies must be substantial." Id. (citing Stup v. UNUM Life Ins. Co., 390 F.3d 301, 308 
directly contrary to evidence in the record do not necessarily amount to an abuse of discretion." "113 Such a deferential standard arises, in part, due to the reality that courts cannot possibly have experience in every industry. ${ }^{114}$ However, " $[t]$ he Board's discretion ... is not unfettered. Its exercise must be supported by substantial evidence." 15 "Substantial evidence is 'such relevant evidence as a reasonable mind might accept as adequate to support a conclusion." 116 Indeed, "[i]gnor[ing] unanimous relevant evidence supporting the award of benefits" almost certainly constitutes an abuse of discretion. $^{117}$

\title{
V. APPEALING A DECISION OF THE RETIREMENT BOARD DENYING BENEFITS IN FEDERAL COURT: A DAUNTING TASK
}

\author{
"The only way [my father] could [often] get to sleep" was by \\ "repeatedly stunning himself, sometimes a dozen times, into
}

(4th Cir. 2004)).

113. Taft v. Equitable Life Assurance Soc'y, 9 F.3d 1469, 1473 (9th Cir. 1993) (citations omitted), abrogated by Saffon v. Wells Fargo \& Co. Long Term Disability Plan, 522 F.3d 863 (9th Cir. 2008).

114. Jani, 209 F. App'x at 313 n.5 (quoting Berry v. Ciba-Geigy, 761 F.2d 1003, 1006 (4th Cir. 1985) ("[T]he standard exists to ensure that administrative responsibility rests with those whose experience is daily and continual, not with judges whose exposure is episodic and occasional.")). The court does not want to "upset the review process the parties have [collectively] bargained for ...." Jones v. Laborers Health \& Welfare Trust Fund, 906 F.2d 480, 482 (9th Cir. 1990). This issue arose in Jani as Appellants argued for "an even higher level of deference than that typically afforded ERISA fiduciaries, because of the knowledge and skill required to assess football injuries in particular." Jani, 209 F. App'x at 314 n.5. According to Appellants, "[t]he Board believes that the complexity of the Plan here and the unique medical and occupational issues faced by professional football players present special challenges to a decision maker, and that experience with meeting those challenges is important." Id. (citation omitted). Notwithstanding that the courts' "knowledge of football-related disability pales in comparison to the Board's knowledge," such a reality "does not militate to bestowing a higher standard than abuse of discretion." Id. "[T] he Board is entitled to the same abuse of discretion review afforded to knowledgeable fiduciaries of any ERISA plan." Id.

115. Jani, 209 F. App'x at 313 (citing Bernstein, 70 F.3d at 788).

116. Id. at 314 (quoting Richardson v. Perales, 402 U.S. 389, 401 (1971)). Such evidence is "more than a mere scintilla." Richardson, 402 U.S. at 401. However, substantial evidence is "less than the weight of the evidence." Consolo v. Fed. Mar. Comm'n, 383 U.S. 607, 620 (1966).

117. Jani, $209 \mathrm{~F}$. App' $x$ at 314 ("Because a fiduciary must present substantial evidence to justify a denial of benefits, it logically follows that a fiduciary appears to abuse its discretion when, in denying benefits, it ignores unanimous relevant evidence supporting the award of benefits."). For example, a fiduciary abuses its discretion when denying benefits "despite the unanimous evidence of three examining doctors agreeing that the claimant was unable to work." Id. (citing Pikulas v. DaimlerChrysler, 397 F. Supp. 2d 883, 892-93 (E.D. Mich. 2005). Moreover, a decision to deny benefits based on an opinion of a non-examining physician "which was contrary to the unanimous opinion of several treating physicians, the fiduciary's own investigator, and the claimant's medical history" constituted an abuse of discretion. Id. (citing Giannone v. Metro. Life Ins. Co., $311 \mathrm{~F}$. Supp. 2d 168, 177-78 (D. Mass. 2004)). A third example given by the Jani court arises when "a plan fiduciary abuses its discretion by crediting a doctor's earlier, incomplete evaluation but ignoring the same doctor's later, more comprehensive opinion." Id. (citing Donovan v. Eaton Corp. Long Term Disability Plan, 462 F.3d 321, 329 (4th Cir. 2006)). 
unconsciousness with a black Taser gun." - Garrett Webster, son of Michael Webster, the only player to successfully obtain reversal of an NFL Retirement Board decision in federal court. ${ }^{18}$

Given the courts' deference to decisions of the Retirement Board, to say that it is difficult to overturn a Retirement Board decision in federal court is certainly an understatement. ${ }^{119}$ In fact, the Retirement Board's decision has been reversed only one time in 25 federal court challenges. ${ }^{120}$ For those

118. Greg Garber, A Tormented Soul, ESPN.COM, Jan. 24, 2005, http://sports.espn.go.com/nfl/ news/story?id=1972285. See infra note 120 and accompanying text (discussing the likelihood of obtaining reversal of a Retirement Board decision in federal court).

119. See id. and accompanying text (stating that there has only been one successful reversal of a Retirement Board decision in federal court).

120. Charles Chandler, Concussions: An NFL Epidemic?, ChARLOTTE OBSERver, Sept. 16, 2007, at $\mathrm{Cl}$ (on file with author); see also NFLPA WHITE PAPER, supra note 41 , at 2 ("96\% of the time the federal courts have upheld the Disability Board's decisions."). Compare Jani, 209 F. App'x 305 (stating that the Retirement Board lacked substantial evidence to justify its denial of Active Football benefits), with Franklin v. Bert Bell NFL Player Ret. Plan, No. 92-1443, 1993 WL 171260 (4th Cir. May 21, 1993) (affirming the district court's grant of summary judgment to the Retirement Board), In re Brumm, 42 F.3d 1394 (8th Cir. 1994), rev'g 995 F.2d 1433 (8th Cir. 1993) (reversing the circuit court's prior holding that Retirement Board arbitrarily and capriciously denied benefits), Webster v. Bert Bel1/Pete Rozelle NFL Player Ret. Plan, No. 96-21130, 1997 WL 680852, at *1 (5th Cir. Sept 22, 1997) (holding that the district court properly concluded that "because substantial evidence indicated that [Plaintiff's] nonfootball related injuries were totally disabling, he was not entitled to ... benefits under the [Retirement] Board's reasonable interpretation of the Plan"), Smith v. Bert Bell/Pete Rozelle NFL Player Ret. Plan, 125 F.3d 859 (9th Cir. 1997), No. 96-56494, 1997 WL 632600, at *1 (9th Cir. Oct. 7, 1997) (unpublished table decision) (citing Plaintiff's work history and medical evidence in suggesting Plaintiff could perform supervisory or other sedentary work provided evidence sufficient for the Retirement Board to deny benefits), Sweeney v. Bert Bell NFL Player Ret. Plan, No. 98-55785, 1998 WL 48012 (9th Cir. Aug. 7, 1998) (holding the district court erred in finding the Retirement Board abused its discretion in determining appellee was not disabled during period in question), Youso v. Bert Bell NFL Ret. Plan, No. 98-1914, 2000 WL 1670886 (8th Cir. Jan. 5, 1998) (affirming the district court's grant of summary judgment to the retirement plan), Green v. Bert Bell/Pete Rozelle NFL Player Ret. Plan, No. Civ.A.3:98-CV-2235-D, 1999 WL 417925 (N.D. Tex. June 22, 1999) (holding the Plan Administrator did not abuse its discretion in denying benefits), Courson v. Bert Bell NFL Player Ret. Plan, 214 F.3d 136 (3d Cir. 2000) (affirming the decision of district court holding Retirement Board's decision to deny pension benefits was not arbitrary or capricious), Williams v. Ret. Bd. of the Bert Bell-Pete Rozelle NFL Player Ret. Plan \& the NFL Player Supplemental Disability Plan, 61 F. App'x 362 (9th Cir. 2003) (finding substantial evidence supported the Retirement Board's decision to deny benefits and did not constitute an abuse of discretion), Boyd v. Bert Bell/Pete Rozelle NFL Players Ret. Plan, 410 F.3d 1173, 1174 (9th Cir. 2005) ("[T]he Plan's Retirement Board . . . did not abuse its discretion in denying [Appellant's] claim for football degenerative disability benefits."), Johnson v. Bert Bell/Pete Rozelle NFL Player Ret. Plan, 468 F.3d 1082 (8th Cir. 2006) (affirming the district court's grant of summary judgment in favor of plan), Morris v. Bert Bell/Pete Rozelle NFL Player Ret. Plan, $208 \mathrm{~F}$. App'x 742 (11th Cir. 2006) (affirming the district court's dismissal of Plaintiff former player's suit), and Washington v. Bert Bell/Pete Rozelle NFL Ret. Plan, 504 F.3d 818 (9th Cir. 2007) (holding that the Retirement Board and Plan did not breach their fiduciary duties by failing to disclose the court 
opposing the NFL and the NFLPA's treatment of disabled players, the litigation involving Mike Webster's disability claims provides a rare look at the NFLPA's mind-set when handling an application for benefits. ${ }^{121}$ Besides providing fodder for those who would criticize the NFL and the NFLPA, ${ }^{122}$ the case involves an instructive illustration of the above discussion of the structure and administration of the Plan. ${ }^{123}$

decision the Retirement Board had previously used to decide that Plaintiff's injury was not a football injury). Armstrong constitutes a bit of an outlier and falls outside of this schematic as it does not constitute a flat-out denial of the player's appeal against the Retirement Board's decision to deny benefits. See Armstrong v. Bert Bell NFL Player Ret. Plan \& Trust Agreement, 646 F. Supp. at 1094, 1097 (D. Colo 1986). While the Armstrong judge was overtly critical of the snail-like speed with which the NFL Retirement Board had considered plaintiff's application for benefits, the court denied Plaintiff's motion for appointment of a receiver as well as Plaintiff's motion for rescission and cancellation of arbitration. Id a at 1095, 1099-1100. The court notes the provisions for arbitration in the Collective Bargaining Agreement which promise that "[t]he arbitrator will, if at all possible considering the arbitrator's schedule and other commitments, issue a written decision within 30 days of the submission of briefs." Id. at 1100 (quoting NFL PLAYERS C.B.A. art. VII, § 10). The court's denial of a receiver comes not from its lack of sympathy to Plaintiff's claims, but rather evinces the court's concern for finding "the most expeditious course of action." Id. Accordingly, the court orders that the case will be rescinded from arbitration "should the proceedings be delayed more than 30 days from the date of the submission of briefs to the arbitrator." Id.; see also discussion infra Part VI.C (discussing the slow administration of claims). Seven lawsuits are pending as of the time of this Comment. See NFLPA WHITE PAPER, supra note 41, at 7.

121. "Because disability claims are protected by privacy laws, the union doesn't disclose who is turned down or why. But the case of Mike Webster, which played out in court, afforded a rare look at its mind-set." Solotaroff, supra note 1; see also Jani v. Bert Bell/Pete Rozelle NFL Player Ret. Plan, 209 F. App'x 305 (4th Cir. 2006), aff'g No. Civ. WDQ-04-1606, 2005 WL 1115250 (N.D. Md. Apr. 26, 2005) (arguing that the Retirement Board lacked substantial evidence to justify denying Mike Webster Active Football benefits).

122. See supra note 25 and accompanying text (discussing the views of Daryl Johnston, outspoken critic of the NFL and the NFLPA).

123. See generally Jani, 209 F. App'x 305; see also discussion supra Part III (discussing structure and administration of the Plan). 


\section{A. The Tragic Life and Times of Mike Webster}

Michael "Iron Mike" Webster played professional football as a center ${ }^{124}$ for the Pittsburgh Steelers from 1974 until 1988 before going on to play two seasons with the Kansas City Chiefs. ${ }^{125}$ In May of $2004,{ }^{126}$ Webster's estate $^{127}$ sued the Plans ${ }^{128}$ under ERISA for damages and monetary relief, ${ }^{129}$ claiming that the Retirement Board abused its discretion in determining Webster was not totally and permanently disabled by the time he left football in 1991. ${ }^{130}$ After numerous failed attempts at employment following his retirement from the game in March 1991, ${ }^{131}$ Webster had contacted the Retirement Board on "five occasions in 1995 and 1996, sometimes only days apart, each time seeking an application for filing a disability claim. ... Not one of these applications was ever completed."132 It was not until the spring of 1999 that Webster completed an application for disability benefits under the Plans, applying for Active Football benefits and, in the alternative, Football Degenerative benefits. ${ }^{133}$

124. Incidentally, the district court notes that the center position on the offensive line "is one of the most exposed and unprotected positions on the football field." Jani v. Bert Bell/Pete Rozelle NFL Player Ret. Plan, No. Civ. WDQ-04-1606, 2005 WL 1115250, at *1 (N.D. Md. Apr. 26, 2005). "The center is the player in the middle of the offensive line and is responsible for snapping the football between his legs to the quarterback to begin each offensive play." Jani, $209 \mathrm{~F}$. App'x at 307. The instant the ball is snapped, "[d]efensive players are permitted to rush at the quarterback...." Id. Accordingly, "[t]he center is particularly vulnerable because he must right himself after the snap to protect the quarterback from the oncoming defensive rush." Id. "[D]efensive linemen [often] used a technique called the 'head slap,' in which they would begin their rush [after the center snapped the football to the quarterback] by slapping the center and other offensive linemen on the sides of their helmet to disorient them." Jani, 2005 WL 1115250 at *1. Such a technique was even outlawed in 1977 "because of its risk to offensive linemen, but players continued to use this and other violent strategies." Id. Perhaps not surprising given his job description, Webster's career as a center left his body battered and broken:

After 17 seasons in the National Football League, Webster had lost any semblance of control over his once-invincible body. His brain showed signs of dementia. His head throbbed constantly. He suffered from significant hearing loss. Three lumbar vertebrae and two cervical vertebrae ached from frayed and herniated discs. A chronically damaged right heel caused him to limp. His right shoulder was sore from a torn rotator cuff. His right elbow grew stiff from once being dislocated. His knees, the cartilage in them all but gone, creaked from years of bone grinding against bone. His knuckles were scarred and swollen. His fingers bent gruesomely wayward.

Garber, supra note 112.

125. Jani, $209 \mathrm{~F}$. App'x at 307. Webster played 245 games, the "most ever by a center and the fifth most in league history." Jani, 2005 WL 1115250 at *1. He was a nine-time Pro-Bowler, won four Super Bowls with the Steelers in the 1970s, was inducted into the Pro Football Hall of Fame in Canton, Ohio, in 1990, and was honored with an election to the NFL all-time team in 2000. Id.

126. See Jani, 2005 WL 1115250, at *4 (“[T]he estate filed suit on May 21, 2004.”).

127. "After he retired, Webster, suffering from symptoms of dementia and chronic pain from football injuries, was unable to earn a living and became homeless. He died of a heart attack [in 
The critical question confronting the Retirement Board in deciding what kind of benefits to award Mr. Webster (and, ultimately, facing the courts in weighing the correctness of the Retirement Board's decision) was one of timing: When did Webster become totally and permanently disabled? ${ }^{134}$ In

2002] at 50." Court: NFL Pension Board 'Abused its Discretion', ESPN.COM, Dec. 14, 2006, http://sports.espn.go.com/nfl/news/story?id=2697301. By all accounts, Webster's last days were horrific and excruciatingly painful. Greg Garber elaborates:

Webster was often laced with a varying, numbing cocktail of medications: Ritalin or

Dexedrine to keep him calm. Paxil to ease anxiety. Prozac to ward off depression.

Klonopin to prevent seizures. Vicodin or Ultram or Darvocet or Lorcet, in various combinations, to subdue the general ache. And Eldepryl, commonly prescribed to patients who suffer from Parkinson's disease.

Garber, supra note 112. By the time of his death, he was frequently making phone calls to friends and family members when not able to locate the way home saying, "All I see is trees." Id.

128. See supra note 108 and accompanying text (explaining that the retirement plan, not the Retirement Board, is the defendant in a civil action under ERISA).

129. 29 U.S.C. $\$ \S 1001-1461$ (2000); see also supra notes 106-107 and accompanying text (explaining that a player can bring a civil action under ERISA).

130. See Jani, 209 F. App'x at 306; see also discussion supra Part IV.C.2 (discussing the deferential standard of review applied by courts in weighing upon decisions by Plan administrators).

131. "After playing sixteen years and sustaining multiple concussions, Webster retired from football in March 1991. His remaining eleven years of life were plagued by a series of failed business ventures and stunted career attempts." Jani, 209 F. App'x at 307. After retirement, Webster first auditioned for a television broadcasting job with NBC in 1991, but was not hired by the network after covering two preseason games. Jani, 2005 WL 1115250, at*1. Webster's wages amounted to "about $\$ 6,000$ in wages in 1991, about $\$ 10,000$ in 1992 for signing sports cards, and about $\$ 1,000$ in 1993 for card signing and appearance fees." Id. While he "made a number of representations about his employment status in 1993 and 1994," such as telling a doctor in May of 1993 that he was currently employed "as a financial investment advisor and real estate manager," none of these endeavors generated revenue. Jani, 209 F. App'x at 307-08. One of his business associates in one of these ventures actually stated, "I think there was something mentally wrong with Mike. His business thinking was very poor." Id. at 308. In 1994, Webster was hired as a strength and conditioning coach for the NFL's Kansas City Chiefs, but " $[t]$ he Assistant General Manager of the Chiefs indicated that Webster was hired 'as a favor' and that he was not 'doing very well during this time period and ... may have been living in his car." Id. (emphasis added). Accordingly, "Webster was mostly unemployed after 1995, earning essentially nothing until his death in 2002." Id.

132. Id.; see also supra note 87 and accompanying text (explaining that completing a written application is the first step in filing a disability claim under the.Plan).

133. Jani, 209 F. App'x at 308, 310.

134. Fundamentally, "[t]he only dispute in Mr. Webster's case was when [he] became unable to work." NFLPA WHITE PAPER, supra note 41 , at 7 . The Jani court's opinion outlines a rather dizzying set of dates, doctors, and medical visits relevant to such a determination. Dates crucial to understanding the case are Webster's retirement from the game in the spring of 1991 and his claim filed in 1999. See supra notes 131-133 and accompanying text. "In support of his claim, Webster submitted his post-retirement medical records and the reports of Dr. Fred Krieg, Dr. James Vodvarka, and Dr. Jonathan M. Himmelhoch." Jani, 209 F. App'x at 310. Between March 1991 and September 1995, "Webster's medical records revealed that he sought medical treatment for certain physical ailments." Id. In May 1993, Webster checked into a hospital under the care of Dr. Stanley Marks, for "'extensive lymphedema,' or fluid collection resulting in swelling . . . " Id. Webster visited Dr. Robert Conn, a cardiovascular specialist, in January 1994, and "Dr. Conn noted in a contemporaneous letter that 'Mr. Webster is capable of most physical activities that would be 
his initial application to the Retirement Board, Webster submitted voluminous medical records ${ }^{135}$ and affidavits ${ }^{136}$ suggesting that his disabilities began while he was still actively playing NFL football. ${ }^{137}$ In fact, one physician submitted that "Webster's disability arose while he was an active player in the NFL and that he was totally and permanently disabled by March 1991,"138 which would have made him eligible for the more generous Active Football benefits. ${ }^{139}$ In response to such evidence, the Retirement Board began its own investigation ${ }^{140}$ and thereafter awarded him

relevant to his age and recreational desires." Id. Another appointment with Dr. Marks in September 1996 resulted in Marks noting that Webster's "life has really deteriorated recently and he is living out of his car. His income has been nominal. He has major problems with depression and obsessive compulsive behavior and is currently being treated with Ritalin and Paxil." Id. That same day, Webster

met with Dr. Jerry Carter, a psychiatrist, because some of his former teammates had 'encouraged him to have an evaluation' after Webster was found sleeping in a local train station. Webster told Dr. Carter that he had been living in hotels and in his car for the previous three-and-one half years.

Id. In fact, Webster confessed he was only living for periodic visits with his children. Id. In late 1997, Dr. Vodvarka saw Webster and recognized he "might be suffering from post-concussion syndrome." Id. In November 1998, Dr. Krieg "diagnosed Webster with brain damage-that is, dementia resulting from his football-related head traumas." Id. Krieg summarized Webster's condition by stating he "had become disabled to the extent that he is substantially unable to engage in any occupation or employment at this time." Id. Upon reevaluation by Dr. Vodvarka, Vodvarka noted in a letter that Webster "would have been able to prove total disability at the time he was released by the Pittsburgh Steelers' because of his dementia and cognitive dysfunction." Id. at 31011. Vodvarka further "linked Webster's mental ailments to the head injuries suffered during his years of football, and concluded that Webster "will never be able to engage in any occupation or employment for remuneration or profit." Id. at 311. As if the above are not enough facts to keep straight, Webster also met with Dr. Himmelhoch, a psychiatrist, starting in March 1999. Id. As a result of the meetings, Himmelhoch wrote in a June 1999 letter to the Plans that Webster suffered from "'traumatic or punch drunk encephalopathy' resulting from football, leaving him totally and permanently disabled." Id. In other words, Webster had "brain disease." Id.

135. See supra note 134 and accompanying text (detailing Webster's extensive medical history prior to and subsequent to filing a claim under the Plan).

136. Webster's affidavit stated that "he had been unable to perform any productive work for the Chiefs during his coaching tenure in 1994 and 1995 because of the crippling nature of his brain damage." Jani, 209 F. App'x at 311 (emphasis added); see also supra note 131 and accompanying text (discussing Webster's employment following his retirement from football). He submitted that "[s]ince completing my football playing years, I have been unable to obtain or keep any type of meaningful and/or gainful employment because of the problems I have experienced from my brain injury." Jani, 209 F. App'x at 311 (brackets in original).

137. Id. at 306.

138. Jani, 2005 WL 1115250 , at *3 (emphasis added).

139. See supra notes 72-74 and accompanying text (explaining that a Player qualifies for Active Football benefits if the disability "arises while the player is an Active Player, and causes the Player to be totally and permanently disabled 'shortly after' the disability(ies) first arises").

140. The Retirement Board "required Webster to be evaluated by a neurologist of its choosing, Dr. 
only T\&P Football Degenerative benefits. ${ }^{141}$ Webster's two appeals to the Retirement Board for Active Football benefits were denied, ${ }^{142}$ and the Retirement Board determined Webster's "onset date"-or when he first became totally and permanently disabled - as September $1,1996{ }^{143}$ In other words, while Webster argued he was totally and permanently disabled by some time in 1990 when he stopped playing football (and was thus eligible for Active Football benefits), ${ }^{144}$ the Retirement Board believed he was not totally and permanently disabled until 1996-six years after his retirement. ${ }^{145}$

The fight that was to ensue in the federal courts over whether the Retirement Board abused its discretion in not awarding Active Football benefits fundamentally concerned two issues: the above-addressed question of timing, and whether a somewhat stingy NFLPA zealously guards its

Edward Westbrook, on June 21, 1999." Jani, 209 F. App'x at 311. A form that the Retirement Board required Westbrook to complete asked when Webster's present disability began, and Webster answered " $3 / 91$ or before." Id. Westbrook further determined that Webster was, indeed, totally and permanently disabled. $I d$.

141. Id.

142. Webster's first appeal was denied by the Retirement Board on May 8, 2000. Id. The Retirement Board discounted the medical report of its own expert, Dr. Westbrook, because it only noted when Webster became "disabled, not when he became totally and permanently disabled." Id.; see also supra note 134 and accompanying text (discussing that Webster had first applied for benefits in the spring of 1999). Second, the Retirement Board did not find Dr. Vodvarka's assessment that Webster was totally and permanently disabled in 1988 to be accurate because Webster had gone on to play two more seasons with the Chiefs. Jani, 209 Fed. App'x at 311; see also supra note 125 (after finishing his employment tenure with the Pittsburgh Steelers, Webster played two season for the Chiefs). The Retirement Board further requested that Webster submit more evidence "showing that he did not work from 1991 onward." Jani, 209 Fed. App'x at 311; see supra notes 131, 136 and accompanying text (discussing Webster's post-football employment). As to Webster's second appeal, notwithstanding that he submitted reports from Drs. Krieg, Himmelhoch, and Kelly, each of whom concluded "to a reasonable degree of professional certainty, that Webster was totally and permanently disabled as of March 1991," the Retirement Board again denied his application for Active Football Benefits. Jani, 209 Fed. App'x at 311 (emphasis added). Its reasoning was twofold:

(1) Webster's work as a broadcaster for two games in 1991, his series of failed business ventures in 1992 to 1994, and his work as an assistant coach for the Chiefs in 1994 and 1995 demonstrated his ability 'to engage[] in any occupation . . . for remuneration or profit'; and (2) the medical evaluation in 1996 by Dr. Marks stating that Webster's life 'has really deteriorated recently' implies that Webster was not mentally disabled during his 1993 visit to Dr. Marks.

Id. at 312 (internal citations omitted); see also supra note 131 and accompanying text (elaborating further upon Webster's post-football employment history). Doug Ell, the lead attorney for the NFL Retirement Plan, elaborates: "It's a very sad case. ... [Webster] was a great, great player. He tried to run all these businesses, all these companies, and, ultimately, it's not clear that any of them succeeded. The Board can't say a guy is permanently disabled just because his businesses failed." Garber, supra note 112.

143. Jani, 209 F. App'x at 312.

144. See supra note 72-74 and accompanying text (defining an "Active Football" disability).

145. See supra note 143 and accompanying text (describing the Retirement Board setting the onset date of T\&P disability at 1996). 
benefits treasury and appears, at least in this case, to award benefits only with considerable reluctance. ${ }^{146}$ As the defendant saw it, because none of the doctors had evaluated Webster for brain damage until $1997^{147}$ and thus the exams were "not performed 'contemporaneous[ly] with the suggested onset date' of Webster's T\&P disability, ... such ex post pronouncements [were] 'speculative and conclusory." 48 Moreover, the Retirement Board

146. Besides the initial submissions of the medical records and affidavits, the Retirement Board responded in 2000 "by again requesting additional documentation to prove Webster's lack of income during the critical 1991 to 1996 period." Jani, 209 F. App'x at 312. Accordingly, "Webster submitted records from the Internal Revenue Service, the Social Security Administration, the Commonwealth of Pennsylvania, the Kansas City Chiefs and the Pittsburgh Steelers, corroborating his assertion that he earned nothing after his retirement other than his coaching salary from the Chiefs." Id. Nonetheless, the Retirement Board decided to hire a private investigator to unearth more details regarding Webster's past employment. $I d$. The investigator was not able to accumulate evidence showing that any of Webster's business endeavors during that time period succeeded. Id. It was during this time that Webster died of a heart attack. Id.; see supra note 127 and accompanying text (discussing the circumstances of Webster's death). Statements made by those siding with the NFLPA seem to buttress such an assertion. "Gene Upshaw, the executive director of the [NFLPA], which seats members on the retirement board, [said] . . the [B]oard would follow the same course of action if presented with a similar case today." Court: NFL Pension Board 'Abused its Discretion', supra note 122. In Upshaw's words:

We all feel badly for what happened to Mike Webster, but obviously there are a lot of players who go through similar circumstances .... But you don't just award a benefit to someone going through a tough time. That's not how it works. [Webster] wasn't denied benefits. It was the question of when those benefits should have started.

Id.; see also supra note 142 and accompanying text (discussing a similar statement made by an attorney for NFL Retirement Plan). The NFLPA's reluctance to pay claims seems to come into clearer focus when it is noted that "the Bert Bell Plan ran up a $\$ 3.5$ million bill for attorneys [in 2006]." Oversight Hearing, supra note 10 (statement of Mike Ditka, ESPN Sports Broadcaster, NFL Hall of Fame Player, and former Head Coach). Such a thorough investigation of applications for benefits approaching a hardened reluctance to pay claims, especially with regard to mental disabilities, did not go unnoticed by the circuit court, though its sympathy was tempered by the Retirement Board's actions:

We are not unsympathetic to the Board's desire to protect Plan assets in the context of claims of mental disability that may be susceptible of misdiagnosis. However, the Board is not without recourse in this situation. As we have discussed, the Plan itself provides the Board with tools to resolve precisely this type of scenario-an applicant submitting medical evidence that is substantial but which the Board does not find dispositive. . . . If the Board still harbored qualms about the strength of Webster's evidence, it could have easily required [him] to submit to such further examinations as, in the opinion of the Retirement Board, are necessary to make an adequate determination respecting his ... mental condition. Instead, the Board truncated its medical investigation and chose to ignore not only the views of Webster's experts but also that of its own.

Jani, 209 F. App'x at 316-17 (internal citations omitted).

147. See supra note 134 and accompanying text (detailing Webster's medical treatment history).

148. Jani, 209 F. App'x at 312; see also supra note 134 and accompanying text (discussing Webster's visits to various physicians and their respective conclusions). 
invoked the forty-two-month limitation provision, ${ }^{149}$ arguing that recovery of any benefits prior to 1996 was time-barred. ${ }^{150}$ Nonetheless, the district court resoundingly granted the Estate's motion for summary judgment against the Plans, finding that the time limitation did not apply because Webster had been suffering brain damage since 1991. ${ }^{151}$

On appeal, the Plans argued two points: the denial of Active Football benefits was a "reasoned exercise of discretion," and, at any rate, the limitations period applied to bar such benefits. ${ }^{152}$ In upholding the decision below, the appellate court went to great pains to demonstrate that deferring to the Retirement Board's discretion would require "a leap of faith" that the law did not permit. ${ }^{153}$ Incredibly, in reaching its decision, the Retirement

149. See supra note 83 and accompanying text (discussing the forty-two-month qualification).

150. The Retirement Board argued that because Webster had not fully filed an application for benefits until 1999 and had provided no evidence that his "mental incapacity substantially interfered with the filing of the claim," recovery of benefits prior to January 1, 1996, was barred. Jani, 209 F. App'x at 312-13.

151. See Jani v. Bert Bell/Pete Rozelle NFL Player Ret. Plan, No. Civ. WDQ-04-1606, 2005 WL 1115250, at *6 (N.D. Md. Apr. 26, 2005) ("Given that Webster had been incapacitated by brain damage since 1991, the Plan's limitations period does not apply to his disability claim."). "The fact that Webster's oncologist did not diagnose his neurological impairments at an earlier date is insufficient, in light of the overwhelming evidence that he had been disabled since 1991, to justify the Plan's determination that he was not disabled until 1996." Id. "Each specialist who examined Webster's neurological status concluded that he was totally and permanently disabled under the terms of the Plan by March 1991." Id.

152. Jani, 209 F. App'x at 313.

153. Id. at 316. The court had first outlined why it would be an abuse of discretion for a plan administrator to ignore unanimous evidence. Id. at 314; see also supra note 117 and accompanying text (ignoring unanimous relevant evidence almost certainly constitutes an abuse of discretion). Such a reality applied not only in a denial of benefits context, but related to other contexts where an abuse of discretion standard was applied. Jani, 209 F. App'x at 314 ("We have required benefits administrators to follow unanimous evidence in other contexts in which we employ an abuse of discretion standard as well."). The court refers to Stawls v. Califano, 596 F.2d 1209 (4th Cir. 1979), where Plaintiff sought a reversal of a denial of disability benefits under the Social Security Act. The court vacated Defendant's decision to deny benefits and remanded the matter for a determination as to why "uncontradicted [medical] evidence . . . should not suffice to afford recovery." Id. at 1213. Though the evidence "might have been less weighty were there conflicting medical opinions, it remained uncontradicted and could not therefore be ignored." Jani, 209 F. App'x at 314 . In the case at hand, Webster's various employment pursuits following his NFL career did not provide substantial evidence that he was not "'substantially unable to engage in any . . employment" between 1991 and 1996." Id. at 315 . For one thing, "his stunted broadcasting career was in fact merely an audition that failed as a result of his diminished cognitive capabilities." Id.; see also supra note 131 and accompanying text (describing Webster's post-football employment history). Also, his stint as a coach with the Chiefs was not relevant to such a determination because he was "employed by an Employer" and "employed out of benevolence." Jani, 209 F. App'x at 315; see also Johnson v. Bert Bell/Pete Rozelle NFL Player Ret. Plan, 408 F. Supp. 2d 807, 811 (D. Minn. 2006), aff'd, 468 F.3d 1082 (8th Cir. 2006) ("The Plan does not refer to the general term 'employer,' but rather to the specific term 'Employer,' which is defined as a member club of the NFL."). Even the Retirement Board"s own investigator "refutes its conclusion that Webster was able to work after retirement." Jani, 209 F. App'x at 316; see also Smith v. Bert Bell/Pete Rozelle NFL Player Ret. Plan, 125 F.3d 859 (9th Cir. 1997), No. 96-56494, 1997 WL 632600, at *1 (9th Cir. Oct. 7. 1997) (unpublished table decision) (finding that applicant Lawrence Edward Smith was "not totally and 
Board had ignored the findings of every medical expert who had examined Webster, including its own expert, not to mention disregarded the conclusions of its private investigator. ${ }^{154}$ Furthermore, the court would not allow the Retirement Board any wiggle room whatsoever as to the tolling provision, finding the Retirement Board did not present substantial evidence upon which to deny Webster the protection of such a provision. ${ }^{155}$ The circuit court held for Webster's estate, much to the relief of his disbelieving family, even going so far as to affirm that the Retirement Board's decision "indicates culpable conduct, if not bad faith." "156

permanently disabled" on the date of his career-ending football injury because he was able to "work as an actor and talent agent" for seven years following his retirement from football).

154. "[T] $]$ he Board truncated its medical investigation and chose to ignore not only the views of Webster's experts but also that of its own." Jani, 209 F. App'x at 317. The Retirement Board "has offered no relevant medical or employment evidence to contradict the unanimous medical opinion of examining experts, even though those opinions were open to challenge." Id.; see also supra note 117 and accompanying text ("[A] fiduciary appears to abuse its discretion when, in denying benefits, it ignores unanimous relevant evidence supporting the award of benefits."). A plan administrator may not "arbitrarily refuse to credit a claimant's reliable evidence, including the opinions of a treating physician." Brandeburg v. Corning Inc. Pension Plan for Hourly Employees, 243 F. App'x 671, 673 (3d Cir. 2007) (quoting Black \& Decker Disability Plan v. Nord, 538 U.S. 822, 823 (2003)). The court found that the evaluations of Webster by several doctors showing that he was "generally in good health" went to his physical health and established nothing at all about his mental state. Jani, 209 F. App'x at 316. Particularly persuasive was the determination by the Retirement Board's own physician that he "was completely and totally disabled as of ... his retirement." Id. In light of this data, the court was incredulous as to how the Retirement Board could find as they did:

Thus, the Plans ask us, in short, to do two things: first, to disregard the testimony of the

Board's own medical expert (in addition to all the others) because it was not "contemporaneous," a fact of which it had to have been aware when it engaged him, and second, to hold that the absence of contemporaneous evidence is itself "substantial evidence." As inclined as we are to defer to the Board's discretion, the law does not permit such a leap of faith.

Id.; see also supra note 117 and accompanying text (ignoring unanimous relevant evidence almost certainly constitutes an abuse of discretion by Plan fiduciaries). More losing arguments were to be made by the Retirement Board. For example, Retirement Board-appointed neutral physicians had been used by the Retirement Board in the past to determine when an applicant became T\&P disabled, so they were not now permitted to argue that such a physician was only used to determine whether a potential claimant suffers from T\&P disability. Jani, 209 F. App'x at 317.

155. Id. at 319. The Plans had first argued that "incapacitated" meant "absolute incompeten[ce]." $I d$. at $318 \mathrm{n} .10$. In addition, they suggested that "[Webster's] numerous requests for disability applications from the Board in 1995 and 1996 . . evidence[d] that he was not mentally incapacitated." Id. at 318; see also infra notes 87, 132 and accompanying text (discussing that a player starts the application process by completing an application, which Webster struggled to do). The court disagreed: "For the tolling provision to have any meaning, it must extend to protect applicants such as Webster, who was so disabled that he could not even open his own mail, ... let alone complete any of the several benefits applications he requested without first securing significant assistance from an attorney." Jani, 209 F. App' $x$ at 317.

156. Id. at $320 \mathrm{n} .11$. "Because there is nothing in this record on which to uphold the Board's 


\section{B. Court Cases Affirming the Retirement Board's Decision}

Equally illuminating is an examination of the legions of cases where the federal courts have gone in the opposite direction and sided with the Plans. ${ }^{157}$ Frequently, the courts parse through an applicant's post-football employment, if such a history exists, to determine whether he was truly totally and permanently disabled at the point he retired from the NFL. ${ }^{158}$ The distinction issue often becomes whether a former player's post-NFL employment refutes or evinces total and permanent disability as of the date

denial of Webster's application for Active Football benefits, the decision of the district court is AFFIRMED." Id. at 320 (emphasis in original). Webster's son, Garrett, stated after the decision came down that "[a]fter all this time, it seems like they'd find some way to weasel out of it. . . But it doesn't look like they'll be able to do it." Court: NFL Pension Board 'Abused its Discretion', supra note 122. Garrett Webster went on to say the following:

It seemed like we battled everyone-the NFL, even the players' union, which should have been the first ones to support our case. ... There is a sadness that my dad's not here to celebrate this, but there is also a happiness that other peoples' voices can be heard, not just NFL players but regular people with brain injuries.

Id. The ruling resulted in "Webster's surviving children and former wife collecting between $\$ 1.5$ million and $\$ 2$ million." Id. Amidst the emotionally-charged circumstances of Webster's tragic death, it is still important to note that even prior to the suit, commensurate with Webster being awarded Football Degenerative benefits, "[t]he NFL already . . . paid Webster and his estate more than $\$ 600,000-\$ 100,020$ annually for the last three years of his life, plus a $\$ 309,230$ retroactive payment . . . to cover his disability from 1996-99." Garber, supra note 112; see supra note 141 and accompanying text (discussing the award of Football Degenerative benefits and important dates).

157. See supra note 120 and accompanying text (citing cases where federal courts have affirmed Retirement Board decisions made under the Plan).

158. See supra notes 60-63 and accompanying text (defining and analyzing total and permanent disability). Crucial to the court's decision against the Plan in Jani was its determination that Mike Webster's stints as a broadcaster and a strength coach, among other positions, did not result in him being considered "employable" for purposes of determining whether he was totally and permanently disabled. See supra note 153 and accompanying text (discussing the court's analysis of Webster's employment history subsequent to his career as a football player). On the other hand, the comparison can be made to cases such as that of Stephen P. Courson. See Courson v. Bert Bell NFL Player Ret. Plan, 75 F. Supp. 2d 424, 433-34 (W.D. Pa. 1999); see also infra notes 164-167 (further analysis of Courson). In upholding the Retirement Board's decision to deny Active Football benefits for Courson, the court noted that "Courson's [post-football] wrestling, weight lifting and book writing activities were significant indicators that Courson was not incapable of engaging in any occupation or employment for remuneration or profit." Courson, 75 F. Supp. 2d at 433-34. His failure to eam "a significant amount of income from such activities" was merely "probative" of T\&P disability, and not determinative enough to reverse the Board's finding that "Courson was not disabled during this period." Id. at 434. Moreover, there are cases like that of Lawrence Edward Smith. See supra note 153 and accompanying text (discussing Smith v. Bert Bell/Pete Rozelle NFL Player Ret. Plan). Smith argued that the "onset date" of his disability should have been set in 1977, when he suffered an injury that ended his football career. Smith v. Bert Bell/Pete Rozelle NFL Player Ret. Plan, 125 F.3d 859, 859 (9th Cir. 1997), No. 96-56494, 1997 WL 632600, at *1 (9th Cir. Oct. 7. 1997) (unpublished table decision). Yet, Smith's "employment history indicated he found work as an actor and talent agent from the time he left professional football in 1977 through 1984." Id. Consequently, he was not eligible for Active Football benefits; even though he became totally and permanently disabled as a result of football activity, Smith was not totally and permanently disabled "shortly after" his on-field injury, but became so gradually. See id.; see also supra note 72 and accompanying text (defining "shortly after"). 
of NFL retirement (or shortly thereafter). ${ }^{159}$ Moreover, fierce battles rage over how "employable" an applicant must be to not be deemed totally and permanently disabled. ${ }^{160}$ Even if such a standard has been met, the issue

159. See supra note 158 and accompanying text (comparing Jani and Smith).

160. Michael McCann reports that ex-New Orleans Saints offensive lineman Conrad Dobler "has been rejected by the Board at least 12 times, without (in his view) adequate reasoning for why his ability to hold down a desk job-which technically prevents him from satisfying the definition of 'totally and permanently disabled'-should preclude recovery for an inability to walk." McCann, supra note 4. Yet, "[a]ctual employment in sedentary positions demonstrates employability in such positions." Williams v. Ret. Bd. Of Bert Bell-Pete Rozelle NFL Player Ret. Plan and NFL Player Supplemental Disability Plan, 61 F. App'x 362, 363 (9th Cir. 2003) (emphasis added); see also supra notes 63, 101 (explaining that someone who is "employable" does not meet definition of total and permanent disability). In Williams, a medical report opined that plaintiff "was able to engage in "supervisory employment." Id. at 362. In other words, since plaintiff "was disabled only with respect to "work which involves any significant requirement for lifting, stooping, stretching, bending, prolonged standing or walking," plaintiff was fully able to "perform supervisory or other sedentary work." Id. at 362-63. In fact, subsequent to retiring from football, Williams had "earned a salary, listed his profession as 'Executive,' and worked for three employers." Id. at 363. Accordingly, the Ninth Circuit held that the Retirement Board had not exceeded its discretion in finding plaintiff to be employable, rather than totally and permanently disabled. Id. A less compelling case is that of former NFL player Daniel Johnson. See generally Johnson v. Bert Bell/Pete Rozelle NFL Player Ret. Plan, 408 F. Supp. 2d 807, 808-10 (D. Minn. 2006), affd, 468 F.3d 1082 (8th Cir. 2006). Johnson, who played professional football from 1982 through 1988, argued "that the appropriate effective start date of his T \& P benefits should be in March of 1997." Johnson, 408 F. Supp. 2d at 808, 810. However, the Retirement Board disagreed, setting his effective start date for benefits at August 1,2002 . Id. at 810 . The court granted summary judgment to the Plan, finding that "Johnson has failed to show that defendant's decision to start his disability benefits on August 1, 2002, was unreasonable." Id. at 811 . Johnson had sustained what would turn out to be a career-ending back injury in 1988 but never "sought medical attention for his back condition before his first application for benefits" in October of 2009 . Id. at 808 . Moreover, opinions of several treating physicians suggested Johnson was capable of sedentary work. Id. at 809-10. Dr. Hanley, the Plan's neutral physician, concluded in October of 2000 that Johnson was not totally and permanently disabled because he could "perform some form of sedentary work." Id. at 809. After his initial application for benefits was denied, Plaintiff applied again in 2002 and was denied again because Dr. Hanley again decided, upon re-evaluation, that Johnson could "probably do sedentary work." Id. at 809 . On July 23,2002 , Johnson was evaluated by Dr. Chebuhar, who noted that "[w]ith regard to return to any gainful employment, this is a difficult question." Id. Moreover, Johnson's tax information "reflected earnings of $\$ 28,145$ in $1997, \$ 26,598$ in $1998, \$ 15,408$ in 1999 , $\$ 11,496$ in $2000, \$ 17,817$ in 2001 and $\$ 23,476$ in $2002 . "$ Id. at 809 . It was not until October of 2002 that a Dr. Bach "examined Johnson and determined he was totally and permanently disabled from any substantial gainful employment." Id. Analyzing the conclusions of Drs. Chebuhar and Bach as to Johnson's condition, the Plan eventually decided that the effective start date of benefits was the month following Johnson's examination by Dr. Chebuhar, or August 1, 2002-because this visit "resulted in the earliest indication of his total and permanent disability within the meaning of the Plan." Id. at 810 . The Defendant acted reasonably in considering Johnson's employment history subsequent to retirement from football, the opinions of the treating physicians, and Johnson's failure to "submit any evidence of medical treatment prior to his November 2001 consultation with Dr. Middlebrooks." Id. In affirming the judgment of the district court, the circuit court stated that "although there is evidence that would support an earlier effective date, a reasonable person could have concluded that Johnson's disability benefits should start on August 1, 2002." Johnson, 468 
then becomes determining the cause of the disability and whether it is truly football-related. ${ }^{161}$

Also of note is litigation concerning the meaning of the phrase "League football activities" for purposes of classifying a disabling condition under the Plan. ${ }^{162}$ Considering the violence of the game, ${ }^{163}$ it should not be surprising to encounter disability applicants arguing that their alcoholism and substance abuse was a direct result of their football careers and not only contributed to, but actually constituted total and permanent disability. ${ }^{164}$ In one instance, a player noted that he started using alcohol-some of which was provided by his football team-as a painkiller, and eventually became addicted. ${ }^{165}$ Consequently, he made the innovative, though ultimately

F.3d at 1088 (circuit court opinion).

161. See supra note 82 and accompanying text (elaborating upon the court's rationale for affirming the judgment of the Retirement Board denying George Webster--to be distinguished from Mike Webster-higher levels of benefits because medical evidence showed that his disability was due to throat cancer and other nonfootball causes).

162. See supra note 72 and accompanying text (discussing that Active Football benefits require a disability arising out of "League football activities").

163. See supra notes 1-10 and accompanying text (discussing how violence has always been a characteristic of football).

164. The case of former Pittsburgh Steelers and Tampa Bay Buccaneers player Stephen $P$. Courson provides an illustration. Courson v. Bert Bell NFL Player Ret. Plan, 75 F. Supp. 2d 424, 426 (W.D. Pa. 1999). Courson claimed that throughout his NFL career "he was exposed to widespread use of anabolic-androgenic steroids ('AAS') among his teammates and other NFL players." Id. at 426 . He appears to suggest that he felt he had to take steroids "to increase his size, strength, speed, and aggression to enable him to compete with other NFL players who used AAS." Id.; see also infra note 165 and accompanying text (discussing Courson's use of alcohol). By late 1988 , two years after his retirement, Courson was diagnosed with "dilated cardiomyopathy," or heart failure, in that his "heart had become flabby and baggy and doesn't pump as a normal heart should." Courson, 75 F. Supp. $2 d$ at 427.

165. See id. at 426 ("Courson contends that he also began ingesting large amounts of alcohol, some of which was provided by the Steelers. Courson states that he used alcohol originally and primarily as a means to control the pain resulting from football injuries. He claims that he became addicted to alcohol because the pain was constant and more alcohol was needed as his tolerance level increased. Courson states that he chose alcohol in lieu of narcotic painkillers, which were frequently provided by team physicians, to quell his pain."). Interestingly, renowned current Indianapolis Colts coach Tony Dungy, in a recent autobiography, recounts that "[d]uring [his] first road trip as a Steeler, everyone was given two beers as [they] boarded the flight home after the game." TONY DUNGY, QUIET STRENGTH: A MEMOIR 45 (2007) (emphasis added). Such a practice, if indeed true, raises interesting issues about assumption of risk in that players might consent to physical contact and pain on the field, but may not assume the risk of elements peripheral to the game, such as being supplied with addictive alcohol or having to play on Astroturf, a dangerous surface. See infra note 182 and accompanying text (discussing assumption of risk in the context of the former widespread use of Astroturf in the NFL as a playing surface). As Courson saw it, "the NFL was aware of his abuse of alcohol and ... the organization took few measures to assist him in overcoming his addiction." Courson, 75 F. Supp. $2 \mathrm{~d}$ at 434 . In its defense, the NFL argued "alcohol was only made available after games and it was the Steelers' policy to limit players to only two cans of beer on the plane ride home from away games." Id at 435 . Moreover, "the players were never required or directed to consume alcoholic beverages." Id. at 435-36. 
unsuccessful, argument that such drug and alcohol use ${ }^{166}$ should be considered a "League football activity" and thus qualify him for a higher classification of benefits (e.g., Active Football). ${ }^{167}$ The court proved to be unreceptive to such a claim. ${ }^{168}$

Perhaps equally enlightening is the controversial case of former Minnesota Vikings offensive linemen ${ }^{169}$ Brent Boyd, which sheds light on the Plan's treatment of brain-related injuries. ${ }^{170}$ Boyd was employed by the Vikings from his entrance into the league in 1980 until his retirement prior to the 1987 season. ${ }^{171}$ After being denied a claim for benefits in 1997 that made no mention of "brain injuries or head trauma," Boyd again applied in June 2000, "this time citing alleged organic brain problems as the result of an alleged head trauma." "172 In making the determination whether Boyd

166. See supra notes 164-165 and accompanying text (detailing Courson's drug and alcohol use).

167. Courson, 75 F. Supp. $2 \mathrm{~d}$ at 429 ("Courson contended that his use of [steroids] and alcohol during his football career was to blame for his disabling heart condition; and that such use should be considered 'League football activities' for purposes of the Player Retirement Plan's disability classification scheme."); see also supra notes 71-82 and accompanying text (discussing the Plan's four-tier classification system). "From April 1986 until [his] release from Tampa Bay, [he] found it difficult to concentrate on certain aspects of required football training because of [his] excessive drinking." Courson, 75 F. Supp. 2d at 432. In fact, Courson went so far as to describe his alcohol use as "out of control." Id. Courson had previously been given Inactive benefits, but had petitioned the Retirement Board to "reclassify his disability into one of the three higher-paying classifications." subsequent to the implementation of the New Plan. Id. at 429. Ultimately, the court sided with the Retirement Board. First, the medical evidence tying use of AAS to congestive heart failure was speculative at best. Id . at 436 . Further, the court found that "[t]he record overwhelmingly supports the Retirement Board's conclusion that Courson decided to overindulge in alcohol ... on his own initiative." Id. While the Retirement Board did admit that Courson's abuse of alcohol may have caused his condition, his consumption was decidedly not a football activity. Id. at 437 . Even though he became disabled due to heart failure in November 1988, and even though such a condition stemmed from alcoholism during his playing days, such disability did not occur "shortly after" as "he was not disabled from such condition within 12 months of his ceasing to be an active player." Id. at 438 .

168. See supra note 167 and accompanying text (discussing the court's rationale in upholding the Retirement Board's decision).

169. Boyd provided a memorable definition of an offensive lineman in his opening brief to the court: "The purpose of an offensive lineman is simple: he must become the irresistible force moving the defense or the immovable object precluding the undaunted pass nush." Boyd v. Bert Bell/Pete Rozelle NFL Players Ret. Plan, 410 F.3d 1173, 1174 n.1 (9th Cir. 2005).

170. Boyd is an outspoken critic of the NFL and NFLPA's interpretation of the Plan, and a passionate advocate of the rights of former football players. See supra notes 10, 78, 88, 95-96, 100, 120, 169 and accompanying text; see also infra notes 182, 191, 194 and accompanying text (providing examples of Boyd's oral advocacy for the needs of former players).

171. Boyd, 410 F.3d at 1174 .

172. Id. at 1175. Boyd's initial application "claimed benefits based on orthopedic joint problems that resulted from NFL injuries." Id. Moreover, and quite importantly, "his medical history before 2000 reveals reports and diagnoses of alcohol abuse, depression, digestive tract disorders, and 
qualified for Football Degenerative disability benefits, pursuant to Plan procedures, ${ }^{173}$ the Retirement Board scrutinized the medical opinions of numerous health professionals he had visited, including the three physicians they had ordered Boyd to consult. ${ }^{174}$ Ultimately, the Retirement Board

hypertension, but no complaints or findings of brain disorders or injuries." Id. It was not until the second application that Boyd mentioned brain problems. Id. "Boyd claims that he was knocked unconscious during a preseason game in August 1980, and that despite having temporary blindness in his right eye during the game, he continued to play." Id. In his testimony before the Senate subcommittee, Boyd elaborated on such claims:

My concussions started in August 1980 ... [and] that was one of only God knows how many concussions I suffered. ... We didn't even count concussions or keep track of them back then, a concussion was not considered a serious injury, as opposed to an injury to a weight bearing bone. A concussion was a 'nuisance' injury, like getting hit in the funny bone. It's a pain in the butt, hurts like heck for a while. . . . [Y]ou surely didn't think getting 'dinged' was going to affect you the rest of your life, and in fact in my case, destroy my life.

Oversight Hearing, supra note 10 (statement of Brent Boyd, former NFL Player). Boyd further claimed that in 1980 he "began experiencing constant headaches," as well as "increasing fatigue, increased forgetfulness, and lack of focus." Boyd, 410 F.3d 1175 . At the time the case was decided, Boyd complained of "a general constant flu-like feeling, fatigue, headaches, queasiness, forgetfulness, intermittent blurred vision, difficulty reading, lack of concentration, learning difficulty, memory loss, dizziness and light-headedness." Id.

173. See supra notes 86-94 and accompanying text (explaining that in the event of a Committee deadlock, a Player may appeal to the Retirement Board, who reviews the applicant's medical records).

174. Boyd, $410 \mathrm{~F} .3 \mathrm{~d}$ at 1176 . The conclusions of such professionals, as might be imagined, are a subject of bitter disagreement between Boyd and the Retirement Board. In Boyd's opinion, "[o]nce [his] team of treating doctors concluded clearly that [he] had suffered organic brain damage from NFL concussions, and that [he] was total[ly] and permanently disabled," the claim was filed with the NFL. Oversight Hearing, supra note 10 (statement of Brent Boyd, former NFL Player). Indeed, at first glance, Boyd does appear to have the overwhelming support of those medical professionals who examined him. Boyd, 410 F.3d at 1173-74. The initial Plan neutral physician, Dr. J. Sterling Ford, "concluded in his narrative report that '[f]rom a neurologic standpoint, [Boyd] does appear to have several problems that may arise out of head injuries suffered in the course of his NFL career. Only further testing will be able to determine the extent of those injuries." Id. at 1176. On a standardized form that the Retirement Board asked him to complete, Ford "checked 'yes' after being asked whether the injury resulted from a football-related activity." Id. Boyd further had himself examined by Dr. Daniel Amen and Dr. Edward Spencer, who "conducted a SPECT (single photon emission computed tomography) brain scan on Boyd, which seeks to measure brain metabolic activity." Id. at 1177. "Without identifying any cause, Dr. Spencer concluded that Boyd 'is disabled due to his brain injury." Id. Following this consultation, the Retirement Board referred Boyd to a Plan neutral psychologist, Dr. Branko Radisavljevic. Id. As Boyd testified, "Dr. Branko enthusiastically support[ed] my claim, and joins every other doctor to this point. Every doctor had the same opinion, it was all one voice that included my own doctors and now TWO NFL doctors." Oversight Hearing, supra note 10 (statement of Brent Boyd, former NFL Player). In support of Boyd's statement, Dr. Branko did check "'yes' when queried whether Boyd's disability resulted from a football-related activity." Boyd, 410 F.3d at 1177 . In fact, the doctor concluded that "Boyd was disabled as a result of "emotional liability depression due to post traumatic organic brain disorder." Id. (emphasis added). Such opinions seemed to suggest that Boyd qualified for Football Degenerative benefits, but, as Boyd tells it, the words that Miki Yaras-Davis of the NFLPA allegedly said to him when he filed a claim (as to the chance that the claim would be granted) would come back to haunt him: "the owners will never open that can of worms." Oversight Hearing, supra note 10 (statement of Brent Boyd, former NFL Player). In 2001, the Retirement Board once again required Boyd to be treated 
denied Boyd's claim for Football Degenerative benefits and awarded him just Inactive T\&P Benefits, noting that "Boyd's disabilities do not arise out of League football activities." 175 Needless to say, such a decision infuriated Boyd, as evidenced by his testimony before the U.S. Senate Subcommittee. ${ }^{176}$ Indeed, the intensity of his testimony echoes the numerous, similar complaints about the administration of the Plan and the difficulty of obtaining a reversal on appeal. ${ }^{177}$

by another physician, this time sending him to Dr. Barry Gordon, the Director of Cognitive Neurology and Neuropsychology and the Memory Clinic at Johns Hopkins Hospital. Boyd, 410 F.3d at 1177. "Boyd was subject to nearly two days of examinations and neuropsychological testing, including a 100-minute examination by Dr. Gordon himself." Id. Dr. Gordon concluded that "the alleged head injury of August, 1980 could not be organically responsible for all or even a major portion of the neurologic and/or neuropsychologic problems that Mr. Boyd is experiencing now, to a reasonable degree of medical probability." Id.

175. Boyd, 410 F.3d at 1177 . In making such a determination, the Retirement Board relied on the statements of examining physician Dr. Gordon, who opined that "the depression that Mr. Boyd is currently experiencing ... could not be an organic consequence of the head injury of August, 1980." Id.; see also supra note 174 and accompanying text (discussing Boyd's treatment history). Boyd has an entirely different take on the story. First, he complains of being "forced to travel from San Diego to Baltimore. . . . to take a sophisticated neuropsychological exam. [He] can take this test at any neuropsychologist in San Diego . . . but they insisted [he] see Gordon and ONLY Gordon." Oversight Hearing, supra note 10 (statement of Brent Boyd, former NFL Player). Boyd continues: "Gordon is not on the list of pre-approved 'neutral' physicians normally used by the Board, he is hand picked .... [ [and] is also walking distance to NFL Benefits headquarters in Baltimore. . . I smell a rat, but we have no choice, [and even] if I don't go I am denied anyway ...." Id. Moreover, Boyd charges that Gordon "didn't bother to look at the existing brain scans and ordered none of his own." Id. Finally, and most compelling, if accurate, Boyd states, "Instead of hiring a neuropsychologist to give me this . . . test they deemed SO important to deciding my case, this neuropsychological test was instead given to me unsupervised by a young grad student in LINGUISTICS, with no medical background." $I d$. Boyd recounts that he only saw Gordon for about thirty minutes: "He bangs my knee with a hammer, tickles the bottom of my feet, and conducts tests I now am told by neurologists were just for show..." Id. Days later, his claim was unanimously denied. Id. The NFLPA, in contrast, argues that Dr. Gordon conducted "an extensive examination," and claims the assistant who performed the test "was well-trained in testing and had performed that test on other patients at least a dozen times before Mr. Boyd." NFLPA WHITE PAPER, supra note 41 , at 13-14.

176. See Oversight Hearing, supra note 10 (statement of Brent Boyd) ("I want to thank you for inviting me to testify, I have an incredible but true story that is guaranteed to open your eyes in anger."). In his introduction, Boyd made it very clear why he was testifying: "I am here for double duty ... to explain to you the cornupt NFL Disability process in general, and to also address the more controversial issue of concussions. The NFL would rather you not look into the topic of head injuries, [and ignore the fact that] their liability is huge." Id.; see also infra note 192 and accompanying text (describing how Boyd's exercises in football practice were geared towards playing through concussions); discussion infra Part VI.B (discussing the NFL's hesitance to acknowledge disability claims for concussions).

177. As an example of another frustrated former football player, Brian DeMarco "has been trying to get disability from the NFLPA for four years. ... [and] has phoned the NFLPA over 100 times in the last [few] months." Gridiron Greats, Brian DeMarco-Retired NFL Player-Jacksonville 


\section{Perceived Problems With the CuRRent PlaN}

As evidenced by the preceding discussion, the difficulty of successfully overturning a decision of the Retirement Board by way of a federal court challenge has caused significant consternation among retirees. ${ }^{178}$ Yet, the degree of deference given to the Retirement Board is not the former players' only point of contention. In actuality, much of the conflict rages over a Plan that numerous retirees believe does not sufficiently address the implications of the dangerous use of Astroturf as a playing surface for many years in the NFL, the debilitating effects of concussion injuries, administrative delays in deciding disability claims, and the cosmetic improvements that fail to address glaring Plan shortcomings.

\section{A. The Widespread Use of Astroturf}

"If you want to know what it feels like to play on AstroTurf, take a piece of indoorloutdoor carpet, lay it down on your blacktop driveway, and let your kids tackle you. Boom!" - John Madden, famed former NFL coach and current NFL television broadcaster ${ }^{179}$

One complaint older NFL retirees have is the widespread use of an artificial playing surface called Astroturf in the late 1960s and early 1970 s. ${ }^{180}$ Former players charge that such a surface was used to save on arena overhead expenses, with no regard for the effect it would have on game participants. ${ }^{181}$ Darryl Johnston, who retired from the NFL in 1999 with a neck injury after eleven seasons as a running back for the Dallas Cowboys, levels accusations that "[f]or decades, the NFLPA has knowingly misled players to believe that artificial turf posed no more threat [of] injury

Jaguars, http://gridirongreats.org/BrianDeMarcoPage.html (last visited Mar. 25, 2009); see also supra note 88 (describing the Gridiron Greats charity effort), and infra note 190 (detailing Brian DeMarco's physical injuries).

178. See supra note 176 and accompanying text (discussing Brent Boyd's irritation at the Retirement Board for determining his disability did not arise out of football activities).

179. Jim Campbell, Commentary, AstroTurf is No Longer, But it Might Have Gotten Unfair Shake, PRO FOOTBALL WKLY., Oct. 9, 2005, http://www.profootballweekly.com/PFW/ Commentary/Columns/2005/campbell2010.htm.

180. "Astroturf basically consisted of a thin, carpet-like cushion between the playing surface and the concrete." Oversight Hearing, supra note 10 (statement of Daryl Johnston, former NFL Player); see also Sw. Recreational Indus. v. FieldTurf, Inc., No. 01-50073, 2002 WL 32783971, at *1 (5th Cir. Aug. 13, 2002) (unpublished decision) ("a carpet-like surface consisting of densely knitted fabric laid over a shock-absorbent foam pad"). Though it "was hailed at first as an end to rain-, mud-, and snow-plagued games, it soon fell out of favor with [both] players and coaches." Campbell, supra note 173. In fact, "a 1995 survey of nearly 1,000 NFL players showed that 93 percent felt that artificial surfaces caused more injuries." $1 d$.

181. See infra note 182 and accompanying text (statements of former NFL Player Gale Sayers in the Senate Subcommittee Hearing leveling such a charge at the NFLPA and the NFL). 
than natural grass." 182 Such a complaint is perhaps simply a manifestation of a larger problem: management indifference to players. ${ }^{183}$ In the shocking

182. Oversight Hearing, supra note 10 (statement of Daryl Johnston, former NFL Player). Johnston comments further on Astroturf:

NFL organizations chose to put down a low-maintenance, synthetic surface to allow for revenue producing events in their stadiums without regard for the damaging effects this hard surface would have on the players' bodies .... As a player, one knows and experiences firsthand on Monday morning, from the aches, pains, bruises, and abrasions that result from playing on an inferior artificial surface the day before.

Id. (emphasis added). Brent Boyd, in his testimony before the Senate Committee, also felt strongly about concussions: "Another issue is the generations who served as guinea pigs for the horrible Astro-Turf playing surfaces. We literally played on concrete, and many concussions did not involve hitting another player but just the ground, and it ruined knees and bodies as well as minds." Id. (statement of Brent Boyd, former NFL Player). If Johnson and Boyd's statements are true, and the NFLPA did indeed know Astroturf was more dangerous of a playing surface than regular grass, such a charge could perhaps be analyzed under a theory that a heightened level of responsibility should be imposed on a person who causes another to be particularly susceptible to harm. An analogous situation can perhaps be found in the conduct of Ford Motor Company in their design of the "Pinto" motor vehicle:

The Ford Pinto case was an outgrowth of a rear-end collision of a Pinto . . . . The collision resulted in the deaths of three teenage girls when their Pinto, equipped with an allegedly faulty gas tank system, burst into flames.

The tragedy was intensified when it came to light that the accident was foreseeable. By the date of the accident, an internal cost-benefit analysis prepared by Ford employees had been made public. The cost-benefit analysis coldly calculated the expected benefits of repairing the Pinto's defective fuel system in terms of lives, injury, and property saved, and compared them to the costs of design modifications. The analysis revealed that, although Ford executives knew that the placement of the tank on the Pinto could cause gas leakage in the case of a rear-end accident, they chose not to adopt a safer design because it would have added to the cost and weight of the vehicle. In short, Ford was caught putting concern for profits ahead of safety.

Steven C. Bennet, Developments in the Movement Against Corporate Crime, 65 N.Y.U. L. REV. 871 , 871-72 (1990) (reviewing FranCIS T. CULlEN ET AL., CORPORATE CRIME UNDER ATTACK: THE FORD PINTO CASE AND BEYOND (1987)) (emphasis added). Former NFL player Gale Sayers would argue the NFL had similar motives in its frequent use of Astroturf:

[F]or the most violent game since the Roman Arena, often played on a surface consisting of concrete covered with a quarter-inch layer of indoor-outdoor carpeting called "Astroturf," which was incorporated in stadium construction to save on grounds-keeping bills, without regards to the havoc it visited on men's bodies.

Oversight Hearing, supra note 10 (statement of Gale Sayers, former NFL Player) (emphasis added). On the other hand, in Hackbart v. Cincinnati Bengals, Inc., 601 F.2d 516 (10th Cir. 1979), the plaintiff, a professional football player, alleged injury resulting from being hit in the head from the rear by another player. See Hackbart, 601 F.2d at 518-19. The court determined that an NFL player assumes the risk of physical harm and injury every time he steps on the field to play. See id. at 520 ("[P]laintiff does not rely on the theory of negligence being applicable ... [i]n recognition of the fact that subjecting another to unreasonable risk of harm, the essence of negligence, is inherent in the game of football, for admittedly it is violent."); see also Gauvin v. Clark, 537 N.E.2d 94, 96 (Mass. 1989) ("Players, when they engage in sport, agree to undergo some physical contacts which could amount to assault and battery absent the players' consent."). However, a football player only 
words of former Dallas Cowboys president Tex Schramm, "[i]f we tell you to play on concrete, you'll play on it!"184 As to the rationale for such a statement, Schramm further remarked, "You're the cattle, we're the ranchers. And we can always get new cattle!" 185 Indeed, "[i]n the only major league sport without guaranteed deals, the majority of players are essentially cows at market-large, anonymous slabs of beef to whom too few in management feel financial loyalty or, for that matter, human concern."186 Citing such statements as evidence, numerous former players argue that they were consistently forced to play through injury and pain by superiors who really had little regard for their long-term health and vitality. ${ }^{187}$ If claims such as Johnston's are true, and the NFL did indeed

consents to that which is "an accepted part of either the playing rules or the general customs of the game of professional football." Hackbart, 601 F.2d at 520. "[I]t is highly questionable whether a professional football player consents or submits to injuries caused by conduct not within the rules ...." Id. at $520-21$. ("[T]he very conduct which was present here is expressly prohibited by the rule[s] . . ."). While an intentional blow to the back of the head is considered outside of the customs of the game, is it less tenable to argue a player does not consent to a playing surface that could potentially cause injury; such a possibility seems well within-or at least closer to-what could be considered the general customs and characteristics of the game. See id.

183. Daryl Johnston came to such a realization after suffering a debilitating injury: "When 1 broke my neck doing what I was trained to do, the league and union told me to get lost. . . The second I couldn't play I was dead meat to them. It was 'So long, see you later, and don't call us."' Solotaroff, supra note 1; see also infra note 186 and accompanying text (discussing management indifference).

184. Gary Smith, Bitter Battle for the Old Guard, SPORTS ILLUSTRATED, Feb. 4, 2008, at 65 .

185. Id.; see also infra note 186 and accompanying text (comparing football players to cattle).

186. Solotaroff, supra note 1. To give an example of a sport with guaranteed deals, the Major League Baseball Collective Bargaining Agreement provides that:

Disability directly resulting from injury sustained in the course and within the scope of his employment under this contract shall not impair the right of the Player to receive his full salary for the period of such disability or for the season in which the injury was sustained (whichever period is shorter), together with the reasonable medical and hospital expenses incurred by reason of the injury and during the term of this contract or for a period of up to two years from the date of initial treatment for such injury, whichever period is longer....

MLB 2007-2011 BASIC AGREEMENT 223 (2007), available at http://mlbplayers.mlb.com/pa/pdf/cba _english.pdf (last visited Mar. 25, 2009). See also infra note 250 and accompanying text (discussing that the Plans provide much less in the way of retirement benefits than the MLB's comparable plan).

187. In an illuminating, if not one-sided, article leveling scathing criticism at the NFL and the NFLPA, Men's Journal recounts such an instance:

He came off the snap and started upfield, the linebacker dead in his sights. Brian DeMarco-6-foot-7 and ripped at 320 pounds; the rare pulling guard who could run like hell and bench press 500-led his tailback, Corey Dillon, into the hole. DeMarco, with a full head of steam, was set to bury the linebacker, put a helmet between his numbers, and plant him, when someone tripped Dillon from behind. Dillon fell crosswise on the back of DeMarco's legs, pinning his knees to the turf. In slo-mo DeMarco was falling forward himself when the linebacker lowered his helmet and drove through DeMarco, knocking his chest downfield as his hips went upfield, practically cleaving him in two.

"I heard the pop in my back as I was going down and just felt this pain like I'd never felt before," says DeMarco, who had recently signed with the Cincinnati Bengals 
"knowingly misle[a]d"188 former players, it would seem as if the NFL and the NFLPA should have a heightened sensitivity to disability claims arising from playing on Astroturf, especially given the explosive nature of statements such as Schramm's. ${ }^{189}$

\section{B. The Phantom Concussion Epidemic}

Additionally, other players have questioned the NFL's recognition and treatment of the seriousness of concussion injuries. ${ }^{190}$ Out of nearly 8,000 vested former players, "only four retired players are receiving total and permanent disability benefits based primarily on concussions suffered

after four solid years with the Jacksonville Jaguars. "I' $m$ at the bottom of the pile under a thousand pounds of guys, and I'm thinking, I'm never getting up. I'll never walk again." In the grand scheme of things, he'd been hit harder: shots that broke ribs and left them slapped on sideways; head-to-head collisions that knocked him senseless and smashed the orbital bone around his eyes; blows that sheared knees and turned elbows inside out. None of those, however, had managed to shove his spine forward on his pelvis and shave off bits of vertebrae like ice chips. Here was terror: DeMarco couldn't work his legs, and the pain between his hips sawed him in half.

They got him to the sideline, where the trainer and his staff laid DeMarco on the bench and tested his legs. He wasn't, in fact, paralyzed, though he couldn't sit up. And so the doctor stepped in and did what doctors have done since the banzai days of Vince Lombardi. He produced a four-inch needle, hiked the player's jersey up, and injected him several times with lidocaine. The numbness set in, DeMarco got to his feet, and, minutes after breaking off bits of spine, reentered the game. He was 27; in a few months he would be out of the sport, a young man with an old man's body.

Solotaroff, supra note 1 (second and third emphasis added). DeMarco's resultant physical condition is grotesque:

His back is fractured in 17 places, his elbows were both shattered, and he has significant nerve damage. Often times his hands do not work and he loses all feeling from them. Due to the severe back injuries, Brian can barley [sic] walk. He also suffered a minimum of 12 concussions and now suffers from headaches and tremors.

Gridiron Greats, Brian DeMarco-Retired NFL Player-Jacksonville Jaguars, http:/gridirongreats. org/BrianDemarcoPage.html (last visited Mar. 25, 2009); see also supra note 177 and accompanying text (outlining DeMarco's struggles in obtaining disability benefits from the NFLPA). Moreover, former guard for the Minnesota Vikings Brent Boyd recounts a similar experience to DeMarco's after taking a "whack" in the head during a game: "I'm laid out, wondering why I can't see, or get up, and then I'm on the sidelines screaming 'I'm blind! I'm blind!' Well, coach comes over and asks if I can see out of one eye, and he sends me back right in." Solotaroff, supra note 1; see also supra note 182 and accompanying text (discussing assumption of risk).

188. See supra note 182 and accompanying text (discussing assumption of risk).

189. See supra notes $184-185$ and accompanying text (discussing Schramm's statements).

190. See supra note 176 and accompanying text (discussing Brent Boyd and others outspoken in their condemnation of the NFL and the NFLPA for being unwilling to recognize the debilitating nature of concussions). 
playing the sport."191 Brent Boyd recounts a practice drill with the Minnesota Vikings where the coaches mimicked concussions to help the players grow more adept at continuing to play after taking repeated blows to the head. ${ }^{192}$ Former NFL defensive lineman Al "Bubba" Baker cuts right to the chase when he states, "I don't have one bad memory from my 13 seasons; I don't have a memory at all, for that matter."193 Renowned Hall of Fame former San Francisco 49ers quarterback Joe Montana comments on the NFL and NFLPA's supposed reluctance to acknowledge the causal link between concussions and other head injuries and, quite frequently, total and permanent disability: "'Once they say there's an issue, then they have to fix it. ... As long as they never admit that there's one, then they never have to fix it. 'They're never going to admit it because then they have to go about and try to correct it." 194 Brent Boyd said "he was [even] told early in the process by an NFLPA benefits employee that he shouldn't bother filing a claim because 'the owners will never open this can of worms by approving a disability claim for a head injury." "195 To such players, the NFLPA is

191. Chandler, supra note 114, at $\mathrm{Cl}$ (emphasis added). Player Agent Leigh Steinberg thinks hundreds, if not thousands of NFL retirees suffer from this "undiagnosed health epidemic." Id. (Steinberg's clients included Hall of Fame quarterbacks Steve Young and Troy Aikman, both of whom "retired early because of recurring head injuries."). Anecdotal evidence seems to back this up: "Al Toon, the best receiver in the history of the New York Jets, ended his career after his ninth concussion, in 1992; . . the oft-concussed Wayne Chrebet, left equally ravaged after the 2005 season and is still debilitated by headaches." Solotaroff, supra note 1 .

192. The drill would be conducted as follows:

We had a drill with the Vikings where they mimicked concussions, though guys called them "dingers" then and laughed about them, like you'd had a few too many at a party. ... "They'd lie you facedown on the Astroturf, spin you around 12 times, then roll a ball out in the other direction and tell you to go get the fumble. Well, sooner or later you'd learn to get that ball when your legs wouldn't go in that direction."

Solotaroff, supra note 1.

193. WHITTINGHAM, supra note 5, at 118.

194. Mike Sullivan, NFL, Union Under Fire for Handling of Disability Claims, N.C. TIMES, June 16, 2007, available at http:/www.dignityafterfootball.org/edwhitearticle.htm. Montana himself suffered "five or six" concussions in his career. Id. In the summer of 2007, the NFL staged a "concussion summit," in which brain scans of several severely disabled retirees were shown to demonstrate that they had the brains "of much older [men]." Solotaroff, supra note 1; see also infra note 1 and accompanying text (discussing the results of brain scans taken of several retirees). However, "[t]he NFL committee's doctors downplayed this as exceptional and sneered at their credentialed critics, dismissing their work as 'soft science."' Solotaroff, supra note 1. Garrett Webster, son of Mike Webster, made an impassioned plea to NFL Commissioner Roger Goodell not to ignore the devastating consequences on human life caused by concussions:

I'm making a plea to you, not as the son of Mike Webster, not as a 23 year-old kid who has lost his best friend and father, but as a young man who desperately wants no one to ever feel the pain that I feel every moming, to feel the loneliness when I feel when I need to turn to my father for advice and he is not there, to feel the heartbreak that I feel when I hear about Chris Benoit, Andre Waters, Reggie White, Justin Strylzick and the web of people connected to them, that have had their [lives] destroyed by repeated concussions and head injuries.

Oversight Hearing, supra note 10 (statement of Garrett Webster, son of former NFL player Mike 
simply engaged in delay tactics by "hoping for the OSHA life expectancy of 52 years ${ }^{196}$ or the destitution and depression to force suicides." ${ }^{197}$ As it stands, the current Plan is chock full of restrictions on the dispensation of benefits for football-related injuries such as concussions, making it easier to deny such claims. ${ }^{198}$ It is no wonder that numerous retirees often characterize the Plan as "Delay, Deny and Hope They Die."

\section{Slow Administration of Claims}

Another complaint is the prolonged amount of time it frequently takes for an application for disability benefits to be processed. ${ }^{200}$ Representatives for the Plan "have often quoted an 'average' processing time of 18 months ...."201 In Armstrong, the court bemoaned the extended time it took the Retirement Board to reach a decision on a former player's application for

Webster). Mike Webster once remarked to a doctor that his daily headaches were "blowing the top of his head off." Greg Garber, Wandering Through the Fog, ESPN.COM, Jan. 27, 2005, http://sports.espn.go.com/nfl/news/story?id=1972288. “Webster's oldest son, Colin, tells the story of the doctor, who, upon examining an MRI of Webster's, asked if he had been in a car accident. 'Yeah,' the old center said, 'about 350,000 car accidents."' Greg Garber, Blood and Guts, ESPN.COM, Jan. 25, 2005, http:/sports.espn.go.com/nfl/news/story?=id1972286. While Webster was never treated by NFL doctors for a concussion, he never complained of symptoms of a concussion. Id. Nonetheless, it is "probable ... that Webster suffered a significant number of head injuries during his career that today would be classified as concussions." Id.

195. Sullivan, supra note 188. Another vivid example is that of former Philadelphia Eagles safety Andre Waters, who committed suicide at the age of forty-four: "Tests of Waters' brain tissue show his brain had degenerated to that of an 85-year-old with early-stage Alzheimer's issues." Id. Daryl Johnston comments on the situation: "It has been proven that almost all medical claims coming from brain trauma due to concussions are denied or only given lesser benefits stating that the injuries and mental issues such as depression and early onset dementia cannot be proven that they are a direct result of football." Oversight Hearing, supra note 10 (statement of Daryl Johnston, former NFL Player).

196. See supra note 10 and accompanying text (explaining that an OSHA study suggests the average life expectancy for a NFL player is fifty-five years, fifty-two for linemen).

197. Oversight Hearing, supra note 10 (statement of Brent Boyd, former NFL player).

198. See discussion infra Part VIl.B (discussing timing deadlines on retroactive disability claims).

199. Smith, supra note 178 , at 70 ; see also supra notes $25,196-197$ and accompanying text (discussing charges of dilatory motives by the Retirement Board in denying claims).

200. See supra note 120 and accompanying text (discussing the the slow administration of the plaintiff's claim in Armstrong v. Bert Bell NFL Player Ret. Plan \& Trust Agreement, 646 F. Supp. at 1094 (D. Colo 1986)).

201. Oversight Hearing, supra note 10 (statement of Gale Sayers, former NFL Player). Sayers goes on to argue that "the processing of claims actually meriting the largest levels of compensation takes a much longer period. Those that cannot be denied immediately are, thus, often delayed inordinately." Id. 
LOD disability benefits under the Old Plan. ${ }^{202}$ As the court noted, "[t]he application dragged on interminably." ${ }^{203}$ In the case of Mike Webster, ${ }^{204}$ "[f]ive years and repeated meetings passed between the Board's initial tabling of Webster's claim for Active Football benefits and its final decision to reject Webster's last appeal."205 On the other hand, however, delays are sometimes necessary to give an applicant additional time to submit further medical and employment information. ${ }^{206}$ Hopefully, such difficulties will be alleviated and the application process will be streamlined by implementing technology such as internet appeals to the Retirement Board ${ }^{207}$ and a claim specialist to increase the likelihood that applications are properly completed the first time. ${ }^{208}$

\section{Is the Plan Really All That Bad?}

Some argue that the existing Plan adequately provides for current players. ${ }^{209}$ After all, the Plan is ostensibly in conformity with ERISA. ${ }^{210}$ To

202. Armstrong, 646 F. Supp. at 1097-98.

203. Id. at 1098 . The court also found that "[t]he institutional and procedural nightmare which gave rise to this horrific and tragic development began on March 11, 1981. On that date, plaintiff filed an application for line-of-duty disability benefits with the board which administers the NFL retirement plan." Id. at 1097 (footnote omitted).

204. See discussion supra Part V.A (discussing Mike Webster's appeal of the Retirement Board's denial of benefits).

205. Jani v. Bell, 209 F. App'x 305, 317 n.9 (4th Cir. 2006). Of course, both sides offer differing arguments as to why such a delay occurred: "Webster's estate insists that the delay arose while the Board was seeking to rationalize its predetermined decision to deny Webster's claim. The Plans, on the other hand, cite this time period as evidence of careful deliberation." Id. (internal citations omitted).

206. See Smith v. Bert Bell/Pete Rozelle NFL Player Ret. Plan, 125 F.3d 859 (9th Cir. 1997), No. 96-56494, 1997 WL 632600, at*1 (9th Cir. Oct. 7, 1997) (unpublished table decision). In Smith, the record even showed that the applicant Lawrence Edward Smith "was partially responsible for the delay because he was tardy in submitting information." Id.; see also supra note 205 and accompanying text (discussing proffered reasons for the delays in the Retirement Board reaching a decision).

207. The NFLPA recently announced that "[t]he retirement board will, whenever possible, decide appeals via email ballots." L. ElAINE HalCHIN, AMERICAN NATIONAL GOVERNMENT AND FINANCE DIVISION, FORMER NFL PlaYeRs: DisABILITIES, BENEFITS, AND RELATED ISSUES 89 (Congressional Research Service 2008), available at http://judiciary.house.gov/hearings/pdf/NFL CRSReport080403.pdf (last visited Mar. 25, 2009). The NFLPA touts that this "will allow for faster decisions on many appeals and will avoid requiring applicants to wait for the next scheduled meeting of the retirement board." Id. at 85 .

208. Id. ("The plan will provide a specialist to receive calls from applicants via a toll-free number. This specialist will assist in preparing applications and advise applicants on the information that is required. The completed application will be sent to the applicant for review, verification and signature. The 45-day review period will begin once the signed application is returned. This service will make it more likely that applications are completed correctly the first time and thus reduce the processing time.").

209. Such an argument seems to be lost amidst all the uproar over the Plan from both the NFLPA and those former players outspoken in their criticism of the current situation. See supra note 88 and 
the credit of the NFL and the NFLPA, recent changes have been made. The 2006 Collective Bargaining Agreement created the "88 Plan," which "provides up to $\$ 88,000$ per year for former players suffering from dementia, without requiring proof that the dementia is football related."211

accompanying text (discussing the animosity between certain retired players and Gene Upshaw). The retirees that have publically supported the NFLPA's treatment of former players go somewhat unnoticed. See QuOTES From ForMER NFL Players ON NFLPA RETIREd Player BENEFITS 1 (2007), available at http://web.archive.org/web/20070710080704/www.nflpa.org/pdfs/NewsAnd Events/What_are_retired_players_saying_about_the_NFLPA's_Retired_Player_Benefits.pdf (on file with author) (last visited Mar. 25, 2009). Jean G. Fuggett, Jr., formerly of the Dallas Cowboys and the Washington Redskins, states that "most of us retired NFL players support what Mr. Upshaw, Mr. Vincent and the NFLPA's Executive Committee and active players do for us. The NFLPA has a long history of helping retired players in many ways, and can proudly stand on its record." Id. at 2. The argument is also made that a disability benefits plan should not be converted to a bail-out system shelling out entitlements. Id. at 2-3. Dan Goich, who played in the NFL from 1967 to 1974 , asserts that " $[t]$ o help someone in need is a noble thing to do, but to financially rescue someone on a continual basis has the potential to have a Pandora's Box-like affect . . the road to hell is paved with good intentions!" Id. at 3. Former Dallas Cowboys, Indianapolis Colts, and Philadelphia Eagles player Brian Baldinger echoes such a point when saying that "the thought of entitlement was exactly the opposite of what I wanted." Id. at 1 . Still others stake part of the issue to poor financial planning by former players; in the words of ex-player Cornelius Bennett, "[t]he problem is that players didn't prepare for life after football." Id:; see also infra note 227 and accompanying text (presenting a counter-argument to financially assisting former players).

210. As Dave Duerson puts it, "[i]n all cases, federal law requires us to follow the terms of the Plan, which states that if an individual is 'employable,' he does not qualify for total and permanent disability. That is not an arbitrary decision being made on the part of the Board . . . It Is The Law!" Oversight Hearing, supra note 10 (statement of Dave Duerson, Trustee for the Burt Bell/Pete Rozelle Retirement Plan and former NFL player). The NFLPA touts that "[v]ested former NFL players who become unable to work - for whatever reason-decades after they leave the game may still receive a disability benefit that serves as income replacement." NFLPA WHITE PAPER, supra note 41 , at 5. This is highly unusual. "An employee of a corporation like IBM or General Motors does not expect to get-and does not get-disability benefits if he or she becomes unable to work decades after leaving the job." NFLPA RESPONSES TO QUESTIONS OF OCTOBER 12, 2007, 3 (2007), available at http://judiciary.house.gov/hearings/pdf/NFLPAExhibitA071105.pdf (last visited Mar. 25,2009 ) (emphasis added). Such an argument seems fatally flawed. First, one federal court has described football as "a species of warfare." Hackbart v. Cincinnati Bengals, Inc., 601 F.2d 516, 518 (10th Cir. 1979); see also supra notes 1-10 and accompanying text (discussing football as a brutally violent sport). It seems that the NFL is unique as compared to non-football positions in that an NFL player's job description is to "put hits" on the players from the other team. See supra note 5 and accompanying text (stating that being "hit" constitutes football working conditions). Being employed in a violent profession might necessitate an enhanced level of benefits as compared to other, non-violent positions. Such a reality also explains why NFL football players frequently may need more than those funds provided by workers' compensation. See Oversight Hearing, supra note 10 (statement of Roger Goodell, Commissioner, National Football League) ("As the Committee knows, the workers' compensation system provides lifetime medical and other benefits to players. NFL disability benefits are in addition to any payments received from those systems.").

211. Id. The Plan is named after former Baltimore Colts player and Hall of Famer John Mackey, who wore the number 88. Id. (statement of Daryl Johnston, former NFL Player). Mackey, who played tight end, now suffers from severe dementia. Id. The plan itself is apparently the first in the 
While such a program is acknowledged as a positive measure by critics, ${ }^{212}$ it is not seen as sufficient. ${ }^{213}$ Additionally, the NFL recently announced the formation of an NFL/NFLPA “"Alliance,' bringing together an initial \$7 million fund to pay for joint replacement surgery and address other financial hardships of retired players." 214 An additional improvement includes a recent decision by the NFL/NFLPA to automatically grant disability claims made by those eligible retirees already receiving social security benefits. ${ }^{215}$

In addition to the previous improvements, the NFL and the NFLPA appear to have taken steps toward ameliorating the effects of what both sides of the argument agree is nothing more than a federally-mandated annoyance: the two-person initial claims Committee. ${ }^{216}$ The NFLPA recently announced

country "that provides special benefits for employees who are afflicted with dementia, even when that dementia occurs decades after their employment has ceased." NFLPA WHITE PAPER, supra note 41, at 25. Under the Collective Bargaining Agreement, payouts to an eligible player include:

(a) For any month in which an eligible player was admitted as an in-patient at an eligible institution for all or part of the month, institutional custodial care, institutional charges, home custodial care provided by an unrelated third party, physician services, durable medical equipment, and prescription medication, up to $1 / 12$ of $\$ 88,000$; and

(b) For any month in which an eligible player was not admitted as an in-patient at an eligible institution for all or part of the month, home custodial care provided by an unrelated third party, physician services, durable medical equipment, and prescription medication, up to $1 / 12$ of $\$ 50,000$

NFL Collective BARgaINING AgREEMENT ARTICLE XLVIII-D (2006-2012), available at http://www.nflplayers.com/images/fck/NFL\%20COLLECTIVE\%20BARGAINING\%20AGREEME NT\%202006\%20-\%202012.pdf (last visited Mar. 25, 2009). With the exception of those players receiving Inactive T\&P disability payouts, "[t]he maximum benefit payable for any month shall be reduced, but not below zero, by the amount of any total and permanent disability benefits paid by the Bert Bell/Pete Rozelle NFL Player Retirement Plan and the NFL Player Supplemental Disability Plan." Id.

212. Oversight Hearing, supra note 10 (statement of Daryl Johnston, former NFL Player) ("This added program is a step in the right direction; however, it is not enough."). The plan began in February 2007 and has paid out in excess of $\$ 500,000$ in benefits. NFLPA WHITE PAPER, supra note 41 , at 25 . Thus far, applicants to the fund are likely to be approved. Id. Out of the 79 applications received as of mid-September $2007,94 \%$ (sixty) of applications processed (sixty-four) have been approved. Id. For their work to create the 88 Plan, NFLPA Executive Director Gene Upshaw and Harold Henderson of the NFL Management Council were honored in May 2007 by the Alzheimer's Association in New York. Id.

213. Oversight Hearing, supra note 10 (statement of Daryl Johnston, former NFL Player) ("[S]ince the Mackey Plan is administered as a reimbursement plan, many qualifying players do not have the front money to participate and obtain care."). Moreover, "[s]urvivors of athletes on the 88 Plan don't receive any disability from the NFLPA, and payments don't kick in till the patient has been deemed unfit to care for himself." Solotaroff, supra note 1.

214. Oversight Hearing, supra note 10 (statement of Gene Upshaw, Executive Director, National Football League Players Association). As Upshaw further remarked, "[j]oint replacement surgeries will be available at no cost to retired players without insurance at designated hospitals across the country." Id. The program is funded by active players. Id.

215. NFLPA WHITE PAPER, supra note 41, at 5. Accordingly, "players already receiving social security benefits will not have to be examined by a Plan doctor." Id. at 6 .

216. See supra note 91 and accompanying text (both the NFLPA and its critics agree that this federally-required initial screening mechanism simply adds to the inefficiency of the claims 
that a "medical director" would be retained to consult with the Committee with the hope of reducing initial denials at the Committee level. ${ }^{217}$ Perhaps this may also ensure consistent application of standards, timely completion of reports, and appropriate oversight as to the performance of neutral physicians. ${ }^{218}$ Finally, the implementation of "physician panels" seeks to "reduce the trips required of people needing to be examined by doctors in different specialties."219 However, such improvements, while certainly helpful, fall short of addressing the heart of the matter and the issues that truly cause contention. Like an elusive offensive running back avoiding defensive tacklers, such measures appear to be just the NFLPA's way of "high-stepping" around the critical shortcomings of the Plan. ${ }^{220}$ Indeed, the Plan remains decidedly unfriendly to retirees. ${ }^{221}$

\section{SUGGESTIONS FOR IMPROVING THE PLAN}

Notwithstanding the recent changes to the Plan, ${ }^{222}$ numerous suggestions for improvement still proliferate. Such proposals better diagnose the crucial shortcomings of the Plan: phraseology that far too frequently allows the Retirement Board to summarily dismiss claims and the difficulty of obtaining a reversal of a Retirement Board decision in federal court. ${ }^{223}$

decision-making process).

217. HALCHIN, supra note 201, at 89 ("The plan will retain a medical director to consult with the two-person initial claims committee and, as needed, with the retirement board to assist in resolving claims. It is expected that this will reduce the number of initial denials at the claims committee level, expediting both initial approvals and the processing of appeals ....").

218. Id.

219. Id. ("The plan will establish a series of physician 'panels' or 'teams,' consisting of doctors with experience in orthopedic and other practices. These teams will be located in areas where there is the largest concentration of retired players, including in Arizona, California, Florida and Texas, as well as in other major metropolitan areas ...."). See also supra note 174 and accompanying text (detailing Brent Boyd's travels to visit different physicians as required by the Retirement Board).

220. "High-stepping" is where an offensive football player raises his legs high in the air while running to avoid defensive tackles, and the phrase also often refers to an offensive player who has ran for significant yardage in a football contest. See, e.g., High-stepping, Balanced Attack of Bears Dumps Rams, ESPN.COM, http://proxy.espn.go.com/nfl/recap?gameld=261211014 (last visited Mar. 25,2009 ) ("The high-stepping rookie got the Rams' home dome rocking with chants of 'Let's Go Bears!' as he set an NFL record with his fifth and sixth returns for touchdowns this season ....").

221. See discussion infra Part VII.A (discussing the problem of poor phraseology being used in the Plan).

222. See discussion supra Part VI.D (discussing recent measures taken by the NFL and the NFLPA to improve the disability claims process).

223. See discussion supra Parts IV.B-C (explaining that much discretion is given to the Retirement Board and how federal courts are extremely hesitant to disturb a Retirement Board decision). 
Moreover, not only do retirees lack representation on the Retirement Board, ${ }^{224}$ but the weakness of the current NFLPA leadership presents yet another obstacle that must be overcome to realize needed Plan changes. ${ }^{225}$

\section{A. Employ Better Phraseology}

One viable suggestion would be to reduce confusion over interpretation of the Plan through "[m]ore obtainable phraseology."226 Retirees frequently charge that in fear of the small number of players who might fraudulently abuse the disability system, the Plan has implemented unduly restrictive language, making recovery under the Plan an arduous task. ${ }^{227}$ As the argument goes, "[t]o protect their economic interests, the NFL and the [NFLPA] have allowed the Plan's procedures to become an obstacle course for former players in order to prevent them from getting benefits."228 First, the language in the Plan allowing the Retirement Board to exercise "full discretion"229 over disposition of disability claims makes it nearly impossible to overturn a decision of the Retirement Board in federal court. ${ }^{230}$ Second, linking T\&P disability to being "employable"231 leads to confusion and dissatisfaction, especially given the Retirement Board's considerably vast interpretation of "employable."232 Indeed, disability applicants unhappy

224. See discussion infra Part VII.C (detailing the constituencies of the Retirement Board).

225. See discussion infra Part VII.D (discussing Gene Upshaw's shortcomings as head of the NFLPA).

226. McCann, supra note 4 ("[T]he NFLPA could collectively-bargain for such authority with the NFL, such as by negotiating down the lofty threshold standards for disability eligibility, most notably the 'totally and permanently and disabled' provision. More obtainable phraseology would result in a higher percentage of successful claims and would not compel Congressional involvement.").

227. Daryl Johnston had this to say:

The NFL may be concerned about the small number of players who might abuse the system, but in ostensibly protecting against this small problem, they are turning their backs on literally hundreds of players who need assistance. The NFLPA looks at this as protecting themselves against a player, however, this is destroying the family unit and quality of life .... There are lots of players in dire need. They were the foundation of the NFL. The league and active players are making millions of dollars. These former players are losing their health, homes, and dignity. Even the great Johnny Unitas was denied disability.

Oversight Hearing, supra note 10 (statement of Daryl Johnston, former NFL Player) (emphasis added).

228. Id.

229. See supra Part IV.B (discussing key provisions of the Plan).

230. See supra note 120 and accompanying text (citing only one applicant that has successfully had a Retirement Board decision under the Plan denying or restricting benefits overturned in federal court).

231. See supra Part III (discussing that being "employable" bars an applicant from obtaining T\&P Disability status).

232. See supra note 160 and accompanying text (detailing former players' complaints that the 
with the Retirement Board's decisions have sought, albeit unsuccessfully, to convince the courts to interpret ambiguous language in the Plan against the Retirement Board. ${ }^{233}$ Such restricted and narrow language gives the Retirement Board, in its full discretion over administration of the Plan, ${ }^{234}$ a multiplicity of loopholes through which to needlessly delay or flatly deny benefits. ${ }^{235}$

\section{B. Eliminate or Extend Timing Deadlines on Retroactive Disability Claims}

Furthermore, due to the proliferation of brain injuries related to concussions, ${ }^{236}$ the forty-two-month limit on retroactive disability amounts should be reconsidered. ${ }^{237}$ In addition, curtailing football-related, Football

\footnotetext{
"employable" requirement allows the Retirement Board to almost summarily dismiss numerous T\&P Disability claims).

233. Stephen P. Courson unsuccessfully sought to argue the application of contra proferentem, a "federal common law rule adopted by the Third Circuit in ERISA insurance cases." Courson v. Bert Bell NFL Player Ret. Plan, 75 F. Supp. 2d 424, 432 (W.D. Pa. 1999). The doctrine of contra proferentem came about for the following reason:

[I]nsurance policies are almost always drafted by specialists employed by the insurer. In light of the drafters' expertise and experience, the insurer should be expected to set forth any limitations on its liability clearly enough for a common layperson to understand; if it fails to do this, it should not be allowed to take advantage of the very ambiguities that it could have prevented with greater diligence. Moreover, once the policy language has been drafted, it is not usually subject to amendment by the insured, even if he sees an ambiguity; an insurer's practice of forcing the insured to guess and hope regarding the scope of coverage requires that any doubts be resolved in favor of the party who has been placed in such a predicament.
}

Heasley v. Belden \& Blake Corp., 2 F.3d 1249, 1257 (3d Cir. 1993). In other words, "the doctrine is used as a tool of last resort to construe an insurance contract that is fairly susceptible of two different interpretations." Courson, 75 F. Supp. 2d at 432. In Courson, however, the court rejected the application of such a doctrine, finding that "the underlying rationale for the doctrine [was] absent ... as the plans at issue were the product of collective-bargaining between two sophisticated parties." Id. (citing Patterson v. Hughes Aircraft Co., 11 F.3d 948, 950 (9th Cir. 1993) ("[T] he rule does not apply to ERISA plans that are the product of collective bargaining agreements reached after arms-length bargaining between parties of equal power . . . .")). Nonetheless, the argument could still be made that retired NFL players, who have no direct representative on the NFLPA, are, in a sense, stuck with a Plan they had no say in creating. See supra note 95 and accompanying text (discussing that retired players have no presence on the Retirement Board); see also discussion supra Part VII.C (discussing retirees' lack of representation on the Retirement Board).

234. See supra note 97 and accompanying text (explaining how the Retirement Board is given vast discretion to decide claims).

235. See discussion supra Part V.B (discussing the difficulty of overturning a Retirement Board decision on appeal to the federal courts).

236. See discussion supra Part VI.B (discussing the high frequency of head injuries in professional football).

237. See supra notes $83-85$ and accompanying text (outlining the parameters of the forty-two- 
Degenerative benefits to those disabilities experienced within fifteen years after retirement does not properly reflect the nature of numerous NFL injuries. ${ }^{238}$ Such changes are critical given the slow-onset nature of totally and permanently debilitating injuries such as concussion-related brain trauma. ${ }^{239}$ Indeed, such temporal limitations are largely to blame for the regrettable reality that only three to four percent of former players are receiving any form of disability benefits whatsoever. ${ }^{240}$ Effectively, the presence of such limitations makes it easier to deny claims for concussions; ${ }^{241}$ a lifting of such time restrictions would give credence to the reality that football-related activity can directly lead to T\&P disability numerous years after retirement. ${ }^{242}$

\section{Give Former Players Representation on the Retirement Board and Increased Access to Plan Information}

"[The retirees]... don't have anybody in the [bargaining] room. Well, they don't and they never will. I'm the only one in that room. They don't even have a vote." - Gene Upshaw ${ }^{243}$

month provision).

238. See Oversight Hearing, supra note 10 (statement of Brent Boyd, former NFL Player) ("[E]liminate the ' 15 years after playing' limit for full benefits, most disabilities don't degenerate into full disabilities until long after that period."); see also supra Part III (Football Degenerative Benefits must be football-related and within fifteen years). This particular requirement came up in the June 26, 2007, Congressional subcommittee meeting. See Alan Schwarz, Congress Scolds N.F.L. and Union, N.Y. TIMES, June 27, 2007, available at http://www.nytimes.com/2007/06/27/ sports/football/27nfl.html ("While discussing the requirement that players file claims no more than 15 years after their retirement, [the NFL senior vice president] said, 'Perhaps we can revisit that'- to which the chairwoman of the subcommittee, Linda T. Sanchez, Democrat of California, testily interjected, 'Perhaps you should revisit that,' before moving on to another witness."); see also supra note 22 (detailing further questioning by Rep. Sanchez).

239. See Oversight Hearing, supra note 10 (statement of Brent Boyd, former NFL Player) ("Most disabilities don't degenerate into full disabilities until long after that period. It is when guys enter their 50's and beyond that these disabilities become debilitating and they can't live on the lesser benefit amount . . . ."). In addition, the fifteen-year after playing limit on full benefits ignores gradual onset of numerous types of football-related disabilities. See id.

240. Oversight Hearing, supra note 10 (statement of Mike Ditka, ESPN Sports Broadcaster, Hall of Fame Player, and former NFL Coach); see also supra note 176 (stating that if the NFL were to acknowledge concussion injuries, their liability would potentially be huge).

241. The statistical evidence certainly seems to support such a contention, as only four retirees are receiving T\&P disability benefits based primarily on concussions suffered during football activity. See supra notes 191, 240 and accompanying text (discussing such data); see also supra note 22 and accompanying text (discussing congressional criticism based on such staggering statistics).

242. See supra notes 1, 194 and accompanying text (discussing scientific conclusions as to the effect of head trauma on selected former NFL players).

243. Smith, supra note 178 , at 65 (quoting Gene Upshaw) (brackets in original); see also supra note 95 and accompanying text (discussing how Upshaw is only elected by current players). 
Another suggestion for improving the Plan would be to provide former professional players with a voice on the Retirement Board through the collective bargaining process. ${ }^{244}$ For example, the Plan could be amended to allow retired players to elect three members of the Retirement Board, adding to the three appointed by the NFL and the three appointed by the NFLPA. ${ }^{245}$ As it currently stands, retired players have no representation on the Retirement Board, and they have no say in the election of NFLPA leaders such as Gene Upshaw. ${ }^{246}$ Adding to the problem, the only information

244. Gene Upshaw is defiant in his attitude toward retired players. See infra note 246 and accompanying text ("They don't hire me and they can't fire me."); see also Oversight Hearing, supra note 10 (statement of Mike Ditka, ESPN Sports Broadcaster, NFL Hall of Fame Player and former NFL Head Coach) ("[P]art of the job of union leadership is to explain to current players that they could be ex-players next week or next month, as a result of injuries or salary cap decisions. It's actually in the interests of current players to push hard for fair, generous disability benefits . ..."). Mike McCann weighs in, noting that because Upshaw is only elected by current players, if he "ignores the wishes of those who cannot vote for him, then former players, much like prospective players, would have no one at the bargaining table when their interests conflict with those of current players, such as in how to divide a pool of retirement funds." McCann, supra note 4. Thanks to such statements, it comes as no surprise that Upshaw is reviled by a number of former players, as Gary Smith creatively chronicles:

Conrad Dobler was near the front of the charge; how could I not remember him? Even with his hair turned white, his legs hobbled by five knee replacements, the old St. Louis Cardinals guard delivered a helmet-first shot. "Some people have no conscience," he snarled, "and he's one of them." Then came a neck-snapping tackle from an old Baltimore Colts safety. "We have no interest in working with a man of his morality," said Bruce Laird. "He is a nonentity . . . He means nothing to retired players." . . Next came a creaking running back and a quarterback, one high and one low. "He is nothing more than a pawn," howled Mercury Morris, the former Miami Dolphin. "This is a scam. It's always been a scam and always will be a scam." Ex-Houston Oilers QB Dan Pastorini's hit was swift and brutal: "He makes me sick." Then it grew worse. One of the eldest ghosts, a onetime Cleveland Browns comerback, arrived like a missile and administered the lowest blow of all. "A habitual liar," Bernie Parrish hissed, and then demanded to know why the man wasn't a suspect in the unusual death of his ex-wife.

Smith, supra note 178, at 64; see also infra note 255 and accompanying text (further discussing former players' dislike for Upshaw).

245. Oversight Hearing, supra note 10 (statement of Brent Boyd, former NFL Player) ("Let retired players select our own 3 advocates to the Board ... ."); see also discussion supra Part IV.B (discussing the implications of the current composition of the Retirement Board). In the alternative, retirees could simply be allowed to vote on the three NFLPA-appointed Retirement Board representatives.

246. Upshaw is acutely aware of this reality, even touting the dictatorship of sorts he enjoys as chief of the NFLPA:

The bottom line is I don't work for [retired players] . . . They don't hire me and they can't fire me. They can complain about me all day long. They can have their opinion. But the active players have the vote. That's who pays my salary. [The retirees] say they don't have anybody in the [bargaining] room. Well, they don't and they never will. I'm the only one in that room. They don't even have a vote. 
currently given out by the Retirement Board is "fragmentary and unreliable."247 Accordingly, transparency should be promoted throughout the process by taking steps such as allowing the retiree and his representatives to sit in on the Retirement Board meeting discussing that player's appeal. ${ }^{248}$ Not only should former players be represented on a Retirement Board that frequently reviews applications from former players for disability benefits, but such a process should be made more accessible through heightened disclosure requirements. ${ }^{249}$

\section{Select NFLPA Leaders That Will Effectively Represent All Players in Collective Bargaining}

Much of the complaints about the current system may all come down to a matter of leverage: unlike players' unions in other professional sports, ${ }^{250}$ the NFLPA regrettably appears to lack sufficient bargaining power to negotiate a satisfactory Plan for all of its potential beneficiaries. ${ }^{251}$ Simply

Smith, supra note 10, at 65 (brackets in original) (emphasis added); see also supra notes 88, 95, 243 and accompanying text (detailing Upshaw's publicly dismissive attitude towards former NFL players).

247. Oversight Hearing, supra note 10 (statement of Mike Ditka, ESPN sports broadcaster, Hall of Fame Player and former NFL Coach). Indeed, former players wish for more access to general information about the administration of the Plan:

Right now, the Plan gives out virtually no information about the number of players receiving disability benefits, how many people get each type of benefit, even the total dollars paid out each year for disability. The information that gets handed out by the Plan-only in response to Congressional and media scrutiny-is fragmentary and unreliable. What we really need is full disclosure by the Bert Bell Plan of all the key information behind the disability benefits, so that the retired players, and the union, can negotiate for better procedures, changes in the way the Plan is administered, and more money for disabled retirees.

Id.

248. Oversight Hearing, supra note 10 (statement of Brent Boyd, former NFL Player) ("Allow players and/or representatives to attend Board meetings - that's not currently allowed (at least not at time of my claim) - especially allow them to attend the final appeals meeting.").

249. See supra note 247 and accompanying text (discussing the paucity of disclosures made by the Retirement Board).

250. For example, as Michael McCann points out, the Executive Director of the Major League Baseball Players Association "negotiated a lucrative pension and disability plan-one that amazingly guarantees a lifetime of healthcare to any player who spends just one day in the big leagues." McCann, supra note 4 (emphasis added). "Although the Plans represent progress for exNFL players, their offerings pale in comparison to retirement benefits obtained by retired MLB players under the MLBPA leadership of Marvin Miller and Donald Fehr." Id. See also supra note 186 and accompanying text (citing to relevant provisions of the Major League Baseball CBA).

251. The statistical data appears to support such an assertion:

But the greater outrage, by far, is what [Upshaw] hasn't accomplished. He failed to win guaranteed contracts in bargaining, failed to get his players long-term health insurance, and failed to get as big a percentage of total revenues as union chiefs have in other sports. Baseball, which took in $\$ 5.1$ billion in revenues in 2006 , provides 10 -year veterans a maximum annual pension of $\$ 180,000$; football, by contrast, which grossed $\$ 6$ billion last 
put, numerous retirees, ${ }^{252}$ and even Gene Upshaw's counterparts in other professional sports such as Major League Baseball, ${ }^{253}$ view his tenure as a colossal failure. ${ }^{254}$ As four-time Super Bowl Champion and Hall of Famer Joe Montana puts it, "[t]he NFL is the worst-represented league, on the players' side, in pro sports.",255

Although one might wish a court would intervene in such a situation, the Courson court ${ }^{256}$ calls for judicial restraint as to skirmishes between the union and its fiduciaries. ${ }^{257}$ While deeply sympathetic to the plight of former football players with profound disabilities, ${ }^{258}$ the court warns that the

season, pays 10-year vets only about $\$ 50,000$ a year. On a yearly basis, according to figures provided by union critic Parrish, baseball pensions average three times the NFLPA's (roughly $\$ 36,000$ to a sub-poverty $\$ 12,000$ ). Some of the greatest men who ever played the game receive pensions of a couple of hundred dollars a month.

Solotaroff, supra note 1. See also supra note 88 and accompanying text (detailing disgust numerous former players have for Upshaw). In faimess, there are those who support Upshaw. For example, Dave Duerson lauded Upshaw before the U.S. Senate Subcommittee, saying that he "personally observed Gene Upshaw and his staff take our union from insolvency to an organization with a ForProfit wing that generates millions of dollars for the players." Oversight Hearing, supra note 10 (statement of Dave Duerson, Trustee for the Burt Bell/Pete Rozelle Retirement Plan and former NFL Player).

252. See supra note 244 and accompanying text (discussing the opinions of numerous retirees regarding Upshaw's effectiveness). Perhaps Joe DeLamielleure says it best: "Nobody thought a guy who'd played with us would throw us under a bus." Smith, supra note 178, at 68; see also supra note 88 and accompanying text (describing Upshaw publically threatening to break DeLamielleure's neck).

253. Interestingly MLBPA Chief Marvin Miller has a low opinion of the effectiveness of Upshaw's leadership of the NFLPA, but does not blame him for it: "Every league's union except the NFL has chosen to hire professional leadership. The NFL Players Association hired a former player. You see the results." Smith, supra note 178, at 70.

254. See supra notes $252-253$ and accompanying text (discussing the antipathy retirees and others have for Upshaw).

255. Solotaroff, supra note 1. Joe DeLamielleure "turns red as a fire ant when asked about Upshaw. 'I won't stop until that bastard's gone or in jail. He's a disgrace to every player, past and current." Id. Mike Mosley chimes in and states that "[The NFL] took it all from me, and never even gave a reason. If you talk to Upshaw-and I tried like hell to-could you ask him how he lives with himself?" Solotaroff, supra note 1. Incidentally, regardless of the validity of the complaints regarding Upshaw's effectiveness, it is undisputed that he is the highest-paid "union chief" in professional sports. Id. ("Upshaw: $\$ 6.7$ million a year, Billy Hunter: $\$ 2.1$ million in basketball; Donald Fehr: \$1 million in baseball.").

256. Courson v. Bert Bell NFL Player Ret. Plan, 75 F. Supp. 2d 424, $439-40$ (W.D. Pa. 1999). See also supra notes 163-167 and accompanying text (discussing how the court in Courson determined that the applicant's alcoholism and substance abuse did not stem from a football-related activity for purposes of determining his level of disability benefits under the Plan).

257. See infra note 259 and accompanying text (discussing the notion of judicial restraint as to disagreements between entities such as the NFLPA and their fiduciaries).

258. The court recognizes that "[i]t would be hard-hearted to lack compassion for [Courson] and for all the young men who are so willing and even eager to sacrifice their lives and bodies for the 
collective bargaining process, not the courts, is the solution to expanding retirement plan coverage. ${ }^{259}$ Such a hands-off approach by the courts furthers an important goal of inexpensively and expeditiously resolving disputes. ${ }^{260}$ As to its rationale, the court thoughtfully notes that while "it is difficult not to question the value system of a society which places Sumolike size and strength above the health and well-being of the human combatants it pays for entertainment," it "is not the role of the court to judge contemporary tastes in sport or entertainment."261 Instead, in the court's opinion, "[i]f the NFL and the players wish to expand the coverage of their retirement plans to include those who find themselves in Mr. Courson's circumstances, it is within their power to do so."262 Such words provide little comfort to retirees. Nonetheless, such an approach by the courts does not impede potential Congressional intervention. ${ }^{263}$ Ultimately, however, whether the federal courts or even Congress ever decide to intervene, the current NFLPA leaders appear incapable and even unwilling to promote the necessary changes in the context of a collective bargaining situation. ${ }^{264}$

sake of this modern American spectacle, and, of course, the fame and fortune it brings to them." Courson, 75 F. Supp. 2d at 439.

259. See id. at $439-40$ ("Nor would it be proper for the court to alter carefully crafted terms and conditions of retirement plans arrived at through the collective bargaining process.").

260. Boyd v. Bert Bell/Pete Rozelle NFL Players Ret. Plan, 410 F.3d 1173, 1178 (9th Cir. 2005) ("Our deferential standard of review furthers a primary goal of ERISA, which endeavors 'to provide a method for workers and beneficiaries to resolve disputes over benefits inexpensively and expeditiously."') (quoting Taft v. Equitable Life Assurance Soc'y, 9 F.3d 1469, 1472 (9th Cir. 1993)).

261. Courson, 75 F. Supp. $2 d$ at 439.

262. Id. at 440 . The court also issues a reminder that "the role of the court in reviewing the discretionary determinations of ERISA fiduciaries is quite limited." Id. One's right to recovery is based "upon the precise language of the governing ERISA plans." Id.; see also supra notes 98-117 and accompanying text (defining and analyzing the abuse of discretion standard of review).

263. It remains to be seen whether Congress will get involved. See Schwarz, supra note 22 ("[Congressional c]ommittee members clearly sided with the former players and said they would consider legislative remedies, perhaps having claims heard by more expeditious arbitration. Several members recommended that ex-players be given a more direct voice in the plan's administration."); see also supra note 22 and accompanying text (citing members of Congress irritated with the shortcomings of the Plan in providing for disabled former players). As of September 18, 2007, the House Judiciary Committee announced that "it has requested a Congressional Research Service ... report to examine the types of health problems suffered by current and former National Football League ... players." Judiciary Committee Requests Report on NFL Injuries, U.S. House of Representatives: Committee on the Judiciary, http://allamericanpatriots.com/48732600_congress_. house_judiciary_committee_requests_report_nfl_injuries (last visited April 23, 2009). House Judiciary Committee Chairman John Conyers, Jr., did state that "[p]rofessional football has grown into a multi-billion dollar industry . . . and I hope the NFL and the players' union can come together to address the needs of the former players." Id. In the words of Linda Sanchez, "[b]ecause the plight of former players has sparked significant congressional interest, the ... study will provide the facts we need as we consider what steps the Congress could take on this issue in the future." Id.

264. See supra notes 251,246 and accompanying text (discussing Upshaw's shortcomings as NFLPA chief and Upshaw's public comments regarding his lack of duty to former players). 


\section{CONCLUSION}

At the end of the day, "the men on the field who generate those billions $^{265}$ are real; they bleed; they break; their brains cloud." 266 The NFL and the NFLPA, while legitimately desirous of protecting Plan assets, ${ }^{267}$ should not neglect the disabling and even terrifying effects such a profoundly violent game can have on former players. ${ }^{268}$ An effective disability Plan, though certainly a reflection upon the strength of NFLPA leadership in the collective bargaining process ${ }^{269}$ must acknowledge the particular and pressing needs of its beneficiaries. ${ }^{270}$ As Daryl Johnston memorably remarked, "[C]oach taught us football is not a contact sportthat if you want a contact sport, then take ballroom dancing. Football is a collision sport."271 Given such a reality, a NFL Disability Plan should properly account for the crushing disabilities suffered by far too many of the approximately 13,000 living retired football players. ${ }^{272}$ For the NFLPA and

265. The NFL was expected to take in $\$ 7$ billion in revenues during the 2007-2008 football season. Solotaroff, supra note 1. See also supra note 4 and accompanying text (discussing the growth and development of the NFL).

266. Solotaroff, supra note 1; see also supra notes 1-10 and accompanying text (discussing the brutality of the game). As former Chicago Bears linebacker Dick Butkus revealed, "my joints hurt so much on Monday morning after a game that I would sometimes have to crawl from bed to the bathroom." WHITTINGHAM, supra note 5, at 115 (emphasis added). In an article analogizing disabled retirees to ghosts on a football field, Gary Smith elaborates upon the disabilities suffered by many household names in football:

Creeping along the sideline on a walker, bent at a 45-degree angle, was the alltime great Oilers running back, Earl Campbell. Confused by foggy memory, neck locking up from damaged vertebrae, advancing on an artificial left hip was Hall of Fame Dallas Cowboys safety Mel Renfro. Dialing his wife because he couldn't remember where he'd parked the car was former All-Pro Carolina Panthers linebacker Kevin Greene. Out of a Maryland homeless shelter, trying to squeeze by on his $\$ 400$-a-month NFL pension was O.J. Simpson's former blocker, Bills tackle Donnie Green. Enough. There were just too many of the hobbling and homeless, the broke and disoriented, to identify them all.

Smith, supra note 178, at 64; see also supra note 244 and accompanying text (outlining Smith's chronicling of former player's dislike for Gene Upshaw).

267. See supra note 146 and accompanying text (citing the court as not unsympathetic to the Retirement Board's desire to protect Plan assets).

268. See supra Part I (discussing the violence of the game); see also supra note 118 and accompanying text (describing how Mike Webster often had to taser himself to fall asleep).

269. See supra Part VII.D (citing many former players' view of Gene Upshaw as an abject failure in his representation of NFL players).

270. See, e.g., supra note 187 and accompanying text (describing Brian DeMarco's horrific, football-related injuries and the difficulties he has encountered trying to obtain Plan benefits).

271. Oversight Hearing, supra note 10 (statement of Daryl Johnston, former NFL Player) (emphasis added).

272. See Chandler, supra note 114 , at $\mathrm{Cl}$ ("There are more than 13,000 living retirees, Upshaw 
the NFL to neglect the urgent needs of retired players in dire need, players who have helped make the game what it is today, would be a tragedy and may even come at the expense of human lives. ${ }^{273}$ It is the solemn duty of the NFLPA and the NFL not to forget these heroic football players, for it is upon their shoulders that the modern game that millions enjoy today has been built.

Brett Edwin LoVellette 274

said in a federal court declaration filed in May.").

273. Michael McCann comes to a similar conclusion: "Of course, the overriding question is 'why': Why have so many of the men who are largely responsible for the league's success, and who now suffer so badly, been forgotten by ... the league they help built ... ?" McCann, supra note 4.

274. J.D. Candidate, 2009, Pepperdine University School of Law; B.S. in Business Management, 2006, Grove City College. The author wishes to thank his parents, the Reverend Dr. and Mrs. Steven Edwin LoVellette; his father, for teaching him to write, and his mother, for devoting herself to his education. He also wishes to thank his brothers, Mark and Will, and his grandparents, Dr. and Mrs. William Edwin LoVellette, and Mr. and Mrs. Samuel Livingston Seward, for their constant support. A final thank you to Tarak Anada, Jeffrey Wyss, and Garrett Llewellyn. 


\section{Appendix}

\section{Exhibit 1: Benefit Credits ${ }^{275}$}

Retirement plan benefits are based on "benefit credits." Players earn a benefit credit for each credited season according to the following exhibit. The amount of money a player will receive each month upon retirement at age fifty-five is equal to the sum of benefit credits for all of a player's credited seasons.

\begin{tabular}{|l|l|}
\hline Credited Season & Benefit Credit \\
\hline Before 1982 & $\$ 250$ \\
\hline $1982-1992$ & 255 \\
\hline 1993 and 1994 & 265 \\
\hline 1995 and 1996 & 315 \\
\hline 1997 & 365 \\
\hline 1998 -final League year & 470 \\
\hline
\end{tabular}

Example: An Active Player for three or more games of the 1996 through 1999 seasons. His Benefits Credits total $\$ 1,620(\$ 315+\$ 365+\$ 470+$ $\$ 470=\$ 1,620$ ). The player will, therefore, receive $\$ 1,465$ per month when he begins to receive his pension benefit at age fifty-five.

Players may be eligible to collect a pension benefit beginning at age fifty-five.

\section{Exhibit 2: Rating System Used to Determine When Line of Duty Benefits are Paid}

- "For orthopedic impairment, using the [American Medical Association] guidelines, LOD benefits are paid if the player meets any of the following thresholds:

- A $38 \%$ or greater loss of use of the entire lower extremity;

- A $23 \%$ or greater loss of use of the entire upper extremity;

275. NFL Players Association, Member Services, Resources, Benefits, http:/www.nflplayers. com/user/template.aspx ?fmid $=181 \& \mathrm{lmid}=344 \&$ pid $=0 \&$ type $=$ c\&weigh $=344,1080,0,0, \mathrm{c}$. (last visited Mar. 24, 2009). 
- An impairment to the cervical or thoracic spine that results in a $25 \%$ or greater whole body impairment;

- An impairment to the lumbar spine that results in a $20 \%$ or greater whole body impairment; or

- Any combination of lower extremity, upper extremity, and spine impairments that results in a $25 \%$ or greater whole body impairment.

- Up to three percentage points may be added to the impairment ratings of a player if he experiences excess pain." 276

276. NFLPA, WHITE PAPER 9-10 (2007), http://nflpa.org/whitepaper/NFLPA_White_Paper.pdf (on file with author) 